\title{
Polycomb Repressive Complex 2 in Eukaryotes-An Evolutionary Perspective
}

\author{
Mallika Vijayanathan ${ }^{1}\left(\mathbb{D}\right.$, María Guadalupe Trejo-Arellano ${ }^{1}$ and Iva Mozgová ${ }^{1,2, * \mathbb{D}}$ \\ 1 Biology Centre, Institute of Plant Molecular Biology, Czech Academy of Sciences, \\ 37005 Ceske Budejovice, Czech Republic; mallika.vijayanathan@umbr.cas.cz (M.V.); \\ maria.trejo@umbr.cas.cz (M.G.T.-A.) \\ 2 Faculty of Science, University of South Bohemia, 37005 Ceske Budejovice, Czech Republic \\ * Correspondence: iva.mozgova@umbr.cas.cz
}

Citation: Vijayanathan, M.; Trejo-Arellano, M.G.; Mozgová, I. Polycomb Repressive Complex 2 in Eukaryotes-An Evolutionary Perspective. Epigenomes 2022, 6, 3 . https://doi.org/10.3390/ epigenomes6010003

Academic Editors: Clara Bourbousse and Sandra Fonseca

Received: 24 November 2021

Accepted: 12 January 2022

Published: 17 January 2022

Publisher's Note: MDPI stays neutral with regard to jurisdictional claims in published maps and institutional affiliations.

Copyright: (C) 2022 by the authors. Licensee MDPI, Basel, Switzerland. This article is an open access article distributed under the terms and conditions of the Creative Commons Attribution (CC BY) license (https:/ / creativecommons.org/licenses/by/ $4.0 /)$.

\begin{abstract}
Polycomb repressive complex 2 (PRC2) represents a group of evolutionarily conserved multi-subunit complexes that repress gene transcription by introducing trimethylation of lysine 27 on histone 3 (H3K27me3). PRC2 activity is of key importance for cell identity specification and developmental phase transitions in animals and plants. The composition, biochemistry, and developmental function of PRC2 in animal and flowering plant model species are relatively well described. Recent evidence demonstrates the presence of PRC2 complexes in various eukaryotic supergroups, suggesting conservation of the complex and its function. Here, we provide an overview of the current understanding of PRC2-mediated repression in different representatives of eukaryotic supergroups with a focus on the green lineage. By comparison of PRC2 in different eukaryotes, we highlight the possible common and diverged features suggesting evolutionary implications and outline emerging questions and directions for future research of polycomb repression and its evolution.
\end{abstract}

Keywords: polycomb; PRC2; H3K27me3; evolution; green lineage; plant; animal; fungi; algae; SAR

\section{Introduction}

DNA in the eukaryotic nucleus winds around octamers of histones, forming nucleosomes, the basic units of chromatin. DNA and histones are subject to chemical modifications, such as methylation, phosphorylation, acetylation, and others, which are instructive for or correlate with chromatin structure. Remodeling of chromatin structure between more open (accessible) or more compact (inaccessible) states by chromatin-modifying and -remodeling complexes governs the distribution of DNA in the nuclear space and allows for gene activation or repression, respectively.

Among crucial modulators of chromatin structure are polycomb group $(\mathrm{PcG})$ proteins, which form multi-subunit polycomb repressive complexes (PRCs) (reviewed in the work of [1-5]). Major PRCs are histone-modifying complexes that confer different and even counteracting enzymatic activities, which mediate gene repression. In animals and plants, PRC1 is an E3 ubiquitin ligase complex that catalyzes histone 2A lysine ubiquitination (H2AKub: K118 in Drosophila, K119 in vertebrates, and K121 in plants) [6-8], and PRC2 is a histone methyltransferase (HMT) complex that catalyzes histone 3 lysine 27 methylation (H3K27me) [9]. Some PRCs catalyze H2Aub removal. In animals, the PR-DUB (polycomb repressive deubiquitinase) complex catalyzes histone H2A deubiquitination, which contributes to gene repression (reviewed in the work of $[10,11]$ ). Similarly, in plants, H2A deubiquitinases UBP12 and UBP13 are implicated in polycomb repression [12,13], but the composition of associated protein complexes remains enigmatic. Additional PRCs have been described in animals, such as Drosophila pleiohomeotic repressive complex (PhoRC) that does not confer enzymatic activity ([14], reviewed in the work of [15]). As histone modifications introduced by PRCs are heritable during mitotic cell divisions (reviewed 
in the work of [16-18]), PRCs provide an epigenetic memory system required for stable cell identity, for an adequate response to external cues, and even for stable repression of genomic repeats (reviewed in the work of [19]). In line with its function in cell identity maintenance in animals, PRC2 dysfunction is frequently associated with cancer development and PRC2 is a potent target for anticancer therapy (reviewed in the work of [20-22]).

PRC1 and PRC2 are conserved in animal and plant models. PRC1 was long considered to be animal specific since a homolog of Polycomb (Pc), the Drosophila PRC1-defining protein subunit [23], is missing in plants. Later, orthologs of PRC1 catalytic subunits RING1 (Really Interesting New Gene 1) and BMI1 (B cell-specific Moloney murine leukemia virus integration site 1) were identified in plants and worms [24]. RING1 and BMI1 were shown to be indispensable for plant development and required for $\mathrm{H} 2 \mathrm{Aub}[7,25,26]$. RING1 and BMI1 orthologs, as well as plant-specific PRC1 subunits, have been found in different plants species ([27], reviewed in the work of [28]). Hence, PRC1 is present in plants, although its core composition differs from animals and may have originated through convergent evolution (reviewed in the work of [28-30]). In contrast to PRC1, PRC2 core composition and H3K27me activity are well conserved throughout eukaryotic lineages, and PRC2 is hypothesized to have emerged through divergent evolution [31]. The evolution of PRC2 has been shaped by genome duplication and subfunctionalization, and the number of different PRC2 complexes tends to rise with increasing body plan complexity (Figure 1) ([32], reviewed in the work of [15,33,34]). In animals, PRC2 catalyzes H3K27 mono, di, and trimethylation (i.e., H3K27me1, H3K27me2, H3K27me3), but in flowering plants, it catalyzes H3K27me3 ([35,36], reviewed in the work of $[9,18])$. In model species of both animals and plants, H3K27me3 is largely associated with transcriptional silencing of developmental genes ([37,38], reviewed in the work of [39,40]). PRC2 composition, its biochemical and developmental functions are well studied in animal and in flowering plant model species, and we refer to recent reviews for detailed information [41-49]. Here, we bring a comparative overview of PRC2 core composition and biochemical function in different eukaryotic groups, with focus on the green lineage, to highlight emerging concepts of PRC2 evolution.

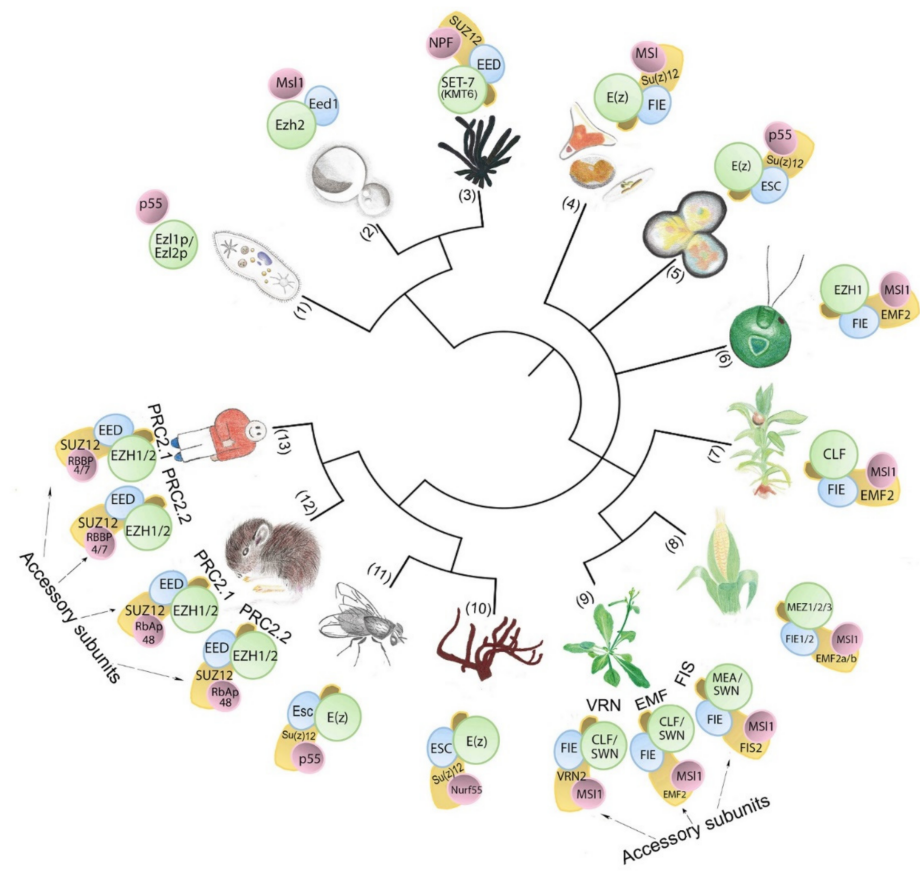

Figure 1. PRC2-core subunit diversity in unicellular and multicellular organisms. The number of subunit homologs and putative PRC2 complexity hypothetically increases with body plan complexity. Numbers in brackets indicate species (1) Paramecium tetraurelia; (2) Cryptococcus neoformans; (3) Neurospora crassa; (4) Phaeodactylum tricornutum; (5) Cyanidioschyzon merolae; (6) Chlamydomonas reinhardtii; 
(7) Physcomitrium patens; (8) Zea mays; (9) Arabidopsis thaliana; (10) Amphimedon queenslandica; (11) Drosophila melanogaster; (12) Mus musculus; (13) Homo sapiens..

\section{Features of PRC2 Core Composition and Function Are Conserved in Animal and Plant Models}

The core of PRC2 is generally composed of four protein subunits that are conserved in multicellular eukaryotic model organisms (Figure 1, Table 1, Supplementary Table S1). The four subunits enhancer of zeste $(\mathrm{E}(\mathrm{z}))$, suppressor of zeste $12(\mathrm{Su}(\mathrm{z}) 12)$, extra sex combs (Esc), and nucleosome remodeling factor (Nurf55, also called p55) are the essential PRC2 components present in D. melanogaster (Figure 2) ([50], reviewed in the work of [15]). E(z) contains the catalytic SET domain (Suppressor of variegation 3-9 (Su(var)3-9), Enhancer of zeste (E(z)), Trithorax (Trx) domain), which is responsible for the HMT activity ([50], reviewed in the work of [51]). Su(z)12 is a VEFS (VRN2-EMF2-FIS2-Su(z)12) domain-containing protein, and Esc and p55/Nurf55 are two WD40 repeat (WDR) domain proteins. $\mathrm{Su}(\mathrm{z}) 12$, Esc, and Nurf55 are non-catalytic subunits that are crucial for PRC2 catalytic activity ([52-55], reviewed in the work of [56]). PRC2 containing all four core components is 1000 times more active than the $\mathrm{E}(\mathrm{z})$ subunit alone [50,57]. Esc and $\mathrm{Su}(\mathrm{z}) 12$ play critical roles in stimulating the HMTase activity of $\mathrm{E}(\mathrm{z})[58,59]$, and the loss of Esc impairs global H3K27me in Drosophila embryos [52,57]. Homologs of Drosophila PRC2 subunits are conserved in mammals, fungi, plants, red algae, and diatoms (Figure 1, Table 1, Supplementary Table S1) ([60-65], reviewed in the work of [66-69]). In mammals, the homologs of E(z), Su(z)12, Esc, and p55 are EZH1 and EZH2, SUZ12, EMBRYONIC ECTODERM DEVELOPMENT (EED), and RETINOBLASTOMA BINDING PROTEINS (RBBP4 or RBBP7), respectively. Minimal PRC2 in mammals comprises the EZH1/2, EED, and SUZ12 subunits in a 1:1:1 stoichiometry [70], and the trimeric core is responsible for H3K27me1/2/3 (reviewed in the work of [71]). RBBP4 or RBBP7, which display 92\% sequence identity, are frequently found together in the same complex, but they may differ functionally, as only RBBP4 is involved in maintaining stem cell identify ([72], reviewed in the work of [73]). Core PRC2 possesses lower activity and/or affinity to target sites unless associated with accessory proteins (reviewed in the work of [56]) that define subtypes of PRC2s ([74], reviewed in the work of $[75,76])$. In humans, two PRC2 subtypes are present based on association with accessory proteins, namely PRC2.1 (contains polycomblike 1-3 (PCL1/2/3), elongin BC and PRC2 (EPOP), PRC2-associated LCOR isoform 1/2 (PALI1/2)), and PRC2.2 (contains jumonji and AT-rich interaction domain-containing 2 (JARID2), adipocyte enhancer-binding protein (AEBP2)) (reviewed in the work of [10]). The molecular structures have been determined for Drosophila, human, mouse, and the fungus Chaetomium thermophilum PRC2 (Figure 2) ([60,77-80], reviewed in the work of $[34,81-84])$. 
A

\begin{tabular}{|c|c|c|c|c|}
\hline & $\begin{array}{l}\text { DNA-bin } \\
\text { (Regula }\end{array}$ & $\begin{array}{l}\text { domai } \\
\text { region) }\end{array}$ & & Catalytic domain \\
\hline$E(z)$ & SANT & SANT & $\mathrm{CXC}$ & SET \\
\hline
\end{tabular}

$\operatorname{Su}(\mathrm{z}) 12$ $\mathrm{ZnF}$ VEFS-Box

B

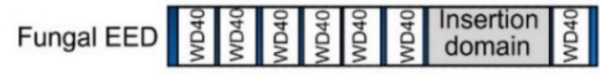

C

\begin{tabular}{|c|c|c|}
\hline Bnd1 & Big protein with & \\
\hline & Ccc1 khrom & Coiled coil \\
\hline
\end{tabular}

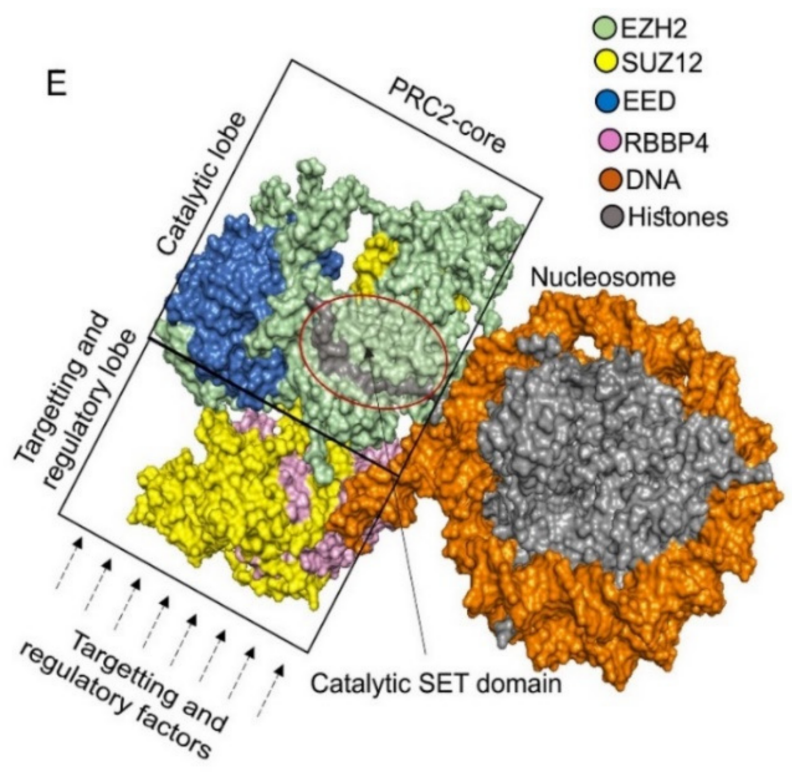

Figure 2. (A) Typical domain architecture of PRC2 core subunits in D. melanogaster. The catalytic subunit E(z) contains SANT (SWI3-ADA2-N-CoR-TFIIIB), CXC (pre-SET domain with C-X(6)-C-X(3)C-X-C motif), and SET (Su(var)3-9, enhancer of zeste, and trithorax domain) domains, and it catalyzes H3K27me through the SET domain. Su(z)12 contains ZnF_C2H2 (cysteine 2-histidine 2 zinc finger domain) and VEFS (VRN2-EMF2-FIS2-Su(z)12) domain and is responsible for assembling the PRC2 complex, while Esc (WD40 repeat protein) helps to stabilize and enhance E(z) activity. P55 (WD40 repeat protein) can bind to histones and $\mathrm{Su}(\mathrm{z}) 12$ and is necessary for nucleosome interaction. (B) Most of the studied fungal Esc homologs EED carry a long insertion domain in their C-terminal part. (C) While $\mathrm{Su}(\mathrm{z}) 12$ is missing, subunits Bnd1 (Big protein with no domains) and Ccc1 (Chromodomain and a coiled coil region) are present in Cryptococcus neoformans. (D) Su(z)12 is missing in C. elegans, but the protein MES-3 (no detectable domains) is a part of the core PRC2. (E) PRC2 core structure. Surface depiction of human PRC2 core complex was created using PyMOL 2.4.1 [85] based on PDB ID: 6WKR [86]; only core subunits are shown. In a catalytically active complex, the EED subunit is encircled by EZH2, and the C-terminal VEFS domain of SUZ12 is sandwiched between the EED and EZH2-SET domain [87]. The region in the circle highlights the lysine binding channel (gray) through which a methyl group is transferred from the cofactor S-adenosylmethionine (SAM)) to the substrate $\mathrm{H} 3$ peptides. The catalytic or targeting and regulatory functions of mammalian PRC2 are separated into two regions within the structure: into the top catalytic lobe (containing EZH, VEFS domain of SUZ12 and EED) and the bottom targeting and regulatory lobe (containing RBBP4/7 and N-terminal SUZ12) (reviewed in the works of $[42,46,84,88]$ ).

Table 1. The distribution of PRC2 core components in different species (more details in the Supplementary Table S1). (Black $\boldsymbol{V}$ indicates prediction and green $\boldsymbol{V}$ indicates experimental evidence; numbers in brackets indicate the number of homologs identified, '?' indicates that the presence or absence is still unclear, and '-' indicates absence.)

\begin{tabular}{|c|c|c|c|c|c|c|c|c|}
\hline Supergroups & $\begin{array}{c}\text { Eukaryotic } \\
\text { Group/Kingdom }\end{array}$ & Phylum or Class & Species & $E(z)$ & Su(z)12 & Esc & p55 & References \\
\hline \multirow{4}{*}{ Archaeplastida } & Eukaryota & Rhodophyta & $\begin{array}{l}\text { Cyanidioschyzon } \\
\text { merolae }\end{array}$ & $\checkmark$ & $\checkmark$ & $\checkmark$ & $\boldsymbol{V}(2)$ & [63] \\
\hline & \multirow{3}{*}{ Viridiplantae } & \multirow{3}{*}{ Chlorophyta } & $\begin{array}{l}\text { Ostreococcus } \\
\text { lucimarinus }\end{array}$ & $\checkmark$ & $\checkmark$ & $\checkmark$ & $\boldsymbol{V}(2)$ & [89] \\
\hline & & & $\begin{array}{l}\text { Chlamydomonas } \\
\text { reinhardtii }\end{array}$ & 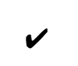 & $\checkmark$ & $\boldsymbol{V}(2)$ & $\boldsymbol{V}(2)$ & {$[63,89]$} \\
\hline & & & Volvox carteri & $\boldsymbol{V}(2)$ & $?$ & $\checkmark$ & $\boldsymbol{V}(2)$ & [89] \\
\hline
\end{tabular}


Table 1. Cont.

\begin{tabular}{|c|c|c|c|c|c|c|c|c|}
\hline Supergroups & $\begin{array}{c}\text { Eukaryotic } \\
\text { Group/Kingdom }\end{array}$ & Phylum or Class & Species & $E(z)$ & Su(z)12 & Esc & p55 & References \\
\hline & \multirow{10}{*}{$\begin{array}{l}\text { Viridiplantae- } \\
\text { Embryophyta }\end{array}$} & $\begin{array}{l}\text { Bryophyta- } \\
\text { Bryopsida }\end{array}$ & $\begin{array}{l}\text { Physcomitrium } \\
\text { patens }\end{array}$ & $\checkmark$ & $\boldsymbol{V}(3)$ & $\checkmark$ & $\boldsymbol{V}(2)$ & {$[61,62,89,90]$} \\
\hline & & $\begin{array}{l}\text { Lycophyte- } \\
\text { Lycopodiopsida }\end{array}$ & $\begin{array}{l}\text { Selaginella } \\
\text { moellendorffii }\end{array}$ & $\boldsymbol{V}(2)$ & $\checkmark$ & $\checkmark$ & $\boldsymbol{V}(3)$ & [89-91] \\
\hline & & Gymnosperm & Picea abies & $v$ & $?$ & $?$ & $?$ & [92] \\
\hline & & & Oryza sativa & $\boldsymbol{V}(2)$ & $\boldsymbol{V}(2)$ & $\boldsymbol{V}(2)$ & $\boldsymbol{V}(2)$ & {$[91,93-96]$} \\
\hline & & & $\begin{array}{l}\text { Triticum } \\
\text { aestivum }\end{array}$ & $\boldsymbol{V}(9)$ & $\boldsymbol{V}(8)$ & $\boldsymbol{v}(7)$ & $\boldsymbol{v}(6)$ & [97] \\
\hline & & & Zea mays & $\boldsymbol{V}(3)$ & $\boldsymbol{V}(2)$ & $\boldsymbol{V}(2)$ & $\boldsymbol{V}(5)$ & [94] \\
\hline & & $\begin{array}{l}\text { Angiosperms- } \\
\text { Monocot }\end{array}$ & $\begin{array}{l}\text { Brachypodium } \\
\text { distachyon }\end{array}$ & $\boldsymbol{V}(2)$ & $\boldsymbol{V}(2)$ & $\boldsymbol{V}(3)$ & $\boldsymbol{V}(4)$ & {$[89,98,99]$} \\
\hline & & & $\begin{array}{l}\text { Hordeum } \\
\text { vulgare }\end{array}$ & $\boldsymbol{V}(3)$ & $\boldsymbol{V}(3)$ & $\checkmark$ & $\boldsymbol{V}(2)$ & {$[94,100,101]$} \\
\hline & & & $\begin{array}{l}\text { Sorghum } \\
\text { bicolor }\end{array}$ & $\boldsymbol{V}(2)$ & $\boldsymbol{V}(3)$ & $\boldsymbol{V}(2)$ & $\boldsymbol{V}(2)$ & [94] \\
\hline & & $\begin{array}{l}\text { Angiosperms- } \\
\text { Eudicot }\end{array}$ & $\begin{array}{c}\text { Arabidopsis } \\
\text { thaliana }\end{array}$ & $\boldsymbol{V}(3)$ & $\boldsymbol{V}(3)$ & $\checkmark$ & $\boldsymbol{V}(5)$ & [102] \\
\hline \multirow{4}{*}{ Chromalveolata } & \multirow{2}{*}{$\begin{array}{c}\text { SAR- } \\
\text { Stramenopiles }\end{array}$} & $\begin{array}{c}\text { Bacillariophyceae } \\
\text { (diatoms) }\end{array}$ & $\begin{array}{l}\text { Phaeodactylum } \\
\text { tricornutum }\end{array}$ & $\checkmark$ & $\checkmark$ & $\checkmark$ & $\checkmark$ & {$[89,103]$} \\
\hline & & $\begin{array}{l}\text { Ochrophyta- } \\
\text { Phaeophyceae }\end{array}$ & Ectocarpus & - & - & - & - & [104] \\
\hline & \multirow{2}{*}{ SAR-Alveolata } & \multirow{2}{*}{ Cilliophora/cilliates } & $\begin{array}{l}\text { Paramecium } \\
\text { tetraurelia }\end{array}$ & $\boldsymbol{V}(2)$ & - & - & $\checkmark$ & {$[31,105,106]$} \\
\hline & & & $\begin{array}{l}\text { Tetrahymena } \\
\text { thermophila }\end{array}$ & $\checkmark$ & $\checkmark$ & $\checkmark$ & $\checkmark$ & {$[107,108]$} \\
\hline \multirow{13}{*}{ Opisthokonta } & \multirow{5}{*}{ Fungi } & Basidiomycota & $\begin{array}{l}\text { Cryptococcus } \\
\text { neoformans }\end{array}$ & $\checkmark$ & - & $\checkmark$ & $\checkmark$ & {$[64,109]$} \\
\hline & & \multirow{4}{*}{ Ascomycota } & $\begin{array}{l}\text { Fusarium } \\
\text { graminearum }\end{array}$ & $\checkmark$ & $\checkmark$ & $\checkmark$ & $\checkmark$ & {$[109,110]$} \\
\hline & & & $\begin{array}{l}\text { Chaetomium } \\
\text { thermophilum }\end{array}$ & $\checkmark$ & $\checkmark$ & $\checkmark$ & $\checkmark$ & [79] \\
\hline & & & & $\checkmark$ & $\checkmark$ & $\checkmark$ & $\checkmark$ & {$[109,111,112]$} \\
\hline & & & $\begin{array}{c}\text { Saccharomyces } \\
\text { cerevisiae }\end{array}$ & - & - & - & - & {$[31,75]$} \\
\hline & $\begin{array}{l}\text { Filasterea- } \\
\text { single-celled } \\
\text { eukaryote }\end{array}$ & Capsaspora & $\begin{array}{l}\text { Capsaspora } \\
\text { owczarzaki }\end{array}$ & - & - & - & - & [113] \\
\hline & \multirow{7}{*}{ Animalia/animals } & Porifera & $\begin{array}{l}\text { Amphimedon } \\
\text { queenslandica }\end{array}$ & $\boldsymbol{V}(4)$ & $\checkmark$ & $\boldsymbol{V}(2)$ & $\checkmark$ & [114] \\
\hline & & Cnidaria/Hydrozoa & Hydra vulgaris & $\checkmark$ & $\checkmark$ & $\checkmark$ & $\checkmark$ & [115-118] \\
\hline & & Insecta/insects & $\begin{array}{l}\text { Drosophila } \\
\text { melanogaster }\end{array}$ & $\checkmark$ & $\checkmark$ & $\checkmark$ & $\checkmark$ & [119-121] \\
\hline & & Nematoda/nematodes & $\begin{array}{l}\text { Caenorhabditis } \\
\text { elegans }\end{array}$ & $\checkmark$ & - & $\checkmark$ & - & {$[122,123]$} \\
\hline & & Reptilia/reptiles & $\begin{array}{c}\text { Anolis } \\
\text { carolinensis }\end{array}$ & $\checkmark$ & $\checkmark$ & $\checkmark$ & $\checkmark$ & [124-127] \\
\hline & & \multirow{2}{*}{ Mammalia/mammals } & Homo sapiens & $\boldsymbol{V}(2)$ & $\checkmark$ & $\checkmark$ & $\checkmark$ & {$[56,60]$} \\
\hline & & & Mus musculus & $\boldsymbol{V}(2)$ & $\checkmark$ & $\checkmark$ & $\boldsymbol{v}$ & {$[128,129]$} \\
\hline
\end{tabular}

The flowering dicot model plant Arabidopsis thaliana has three E(z) paralogs (CURLY LEAF (CLF), SWINGER (SWN) and MEDEA (MEA)), three Su(z)12 paralogs (EMBRYONIC FLOWER 2 (EMF2), VERNALIZATION 2 (VRN2), and FERTILIZATION INDEPENDENT SEED 2 (FIS2)), one ESC homolog (FERTILIZATION INDEPENDENT ENDOSPERM (FIE)), and five p55 homologs (MULTICOPY SUPPRESSOR OF IRA (MSI1-MSI5)), of which only MSI1 is known to be present in PRC2 ([102,130,131], reviewed in the works of $[29,132])$. SWN and CLF play significant roles during vegetative development and phase transitions ([133-138], reviewed in the work of [47,48]), while MEA is required during gametophyte development and early embryogenesis [131,139]. Three PRC2 complexes have been identified in Arabidopsis defined by the presence of respective $\mathrm{Su}(\mathrm{z}) 12 \mathrm{ho}$ mologs: EMBRYONIC FLOWER (EMF), VERNALIZATION (VRN), and FERTILIZATION 
INDEPENDENT SEED (FIS). The EMF and VRN complexes are associated with either CLF or SWN, and the FIS complex contains MEA or SWN as a catalytic subunit ([140-142], reviewed in the work of $[3,69])$. In $A$. thaliana, accessory subunits that can physically interact with core PRC2 subunits have been identified, including several transcription factors, such as the ASYMETRIC LEAVES (AS), TELOMERE REPEAT BINDING FACTORS (TRBs), VIVIPAROUS1/ABI3-LIKE (VAL), additional PRC-chromatin-associated enzymatic or scaffold proteins, such as LIKE HETEROCHROMATIN PROTEIN 1 (LHP1), VERNALIZATION INSENSITIVE 3 (VIN3), VRN5, PWWP-DOMAIN INTERACTOR OF POLYCOMBS 1 (PWO1), INCURVATA11 (ICU11), components of the E3 ubiquitin ligase complexes, components of the DNA replication and chromosome segregation machineries (CTF4) or domesticated transposases (ALP1, ALP2) ([143-149], reviewed in the work of $[3,33,45])$. In spite of the well-described impact of PRC2 function on plant development, plant PRC2 composition and potential subcomplex function remain enigmatic. Additionally, structural and detailed biochemical information on plant PRC2 is not yet available, limiting detailed insight into PRC2 subunit interaction and mechanism of action in plants.

In animals, PRC2 catalyzes H3K27me1/2/3 [50], while in plants, H3K27me1 in centromeres and pericentromeres is catalyzed by the ARABIDOPSIS TRITHORAX-RELATED HMTs (ATXR5 and ATXR6) [150]. H3K27me3 is, therefore, the conserved hallmark of PRC2 enzymatic activity (Figure 3, Supplementary Table S2). H3K27me3 in D. melanogaster occupies broad domains that typically span more than $10 \mathrm{~kb}$ [151]. In mammals, H3K27me3 has two distribution patterns: large domains $(>100 \mathrm{~kb})$ encompassing the Hox loci and smaller domains of a few kilobases (reviewed by the authors of [75]). In addition to genic loci, H3K27me3 and PRC2 reside in poised enhancers (PEs) that often associate with bivalent genes in vertebrate pluripotent cells [152]. While PRC1 contributes to the PE marking globally [152] and also targets active enhancers in cancer cells [153], PRC2 is involved at PEs at specific loci [152]. Unlike in animals, the distribution of H3K27me3 in A. thaliana is usually limited to single genes, with the modification covering proximal parts of promoters and gene bodies with average enrichment regions of 1-1.5 $\mathrm{kb}[37,38,154,155]$. Gene-limited distribution is also found in metabolic gene clusters that are organized in an operon-like manner [156]. In A. thaliana, H3K27me3 decorates approximately $20-30 \%$ of all protein-coding and miRNA genes $[37,38,157]$ that are associated with plant development, hormone metabolism and response, but also with nutrient homeostasis $[158,159]$, stress response $([160,161]$, reviewed in the works of $[5,162,163])$ or primary and secondary metabolism [156,161]. The potential for targeting is nevertheless more extensive, as $64 \%$ of protein-coding genes were identified as H3K27me3 targets when combining different timepoints of $A$. thaliana shoot apical meristem development during the transition to flowering [164]. 

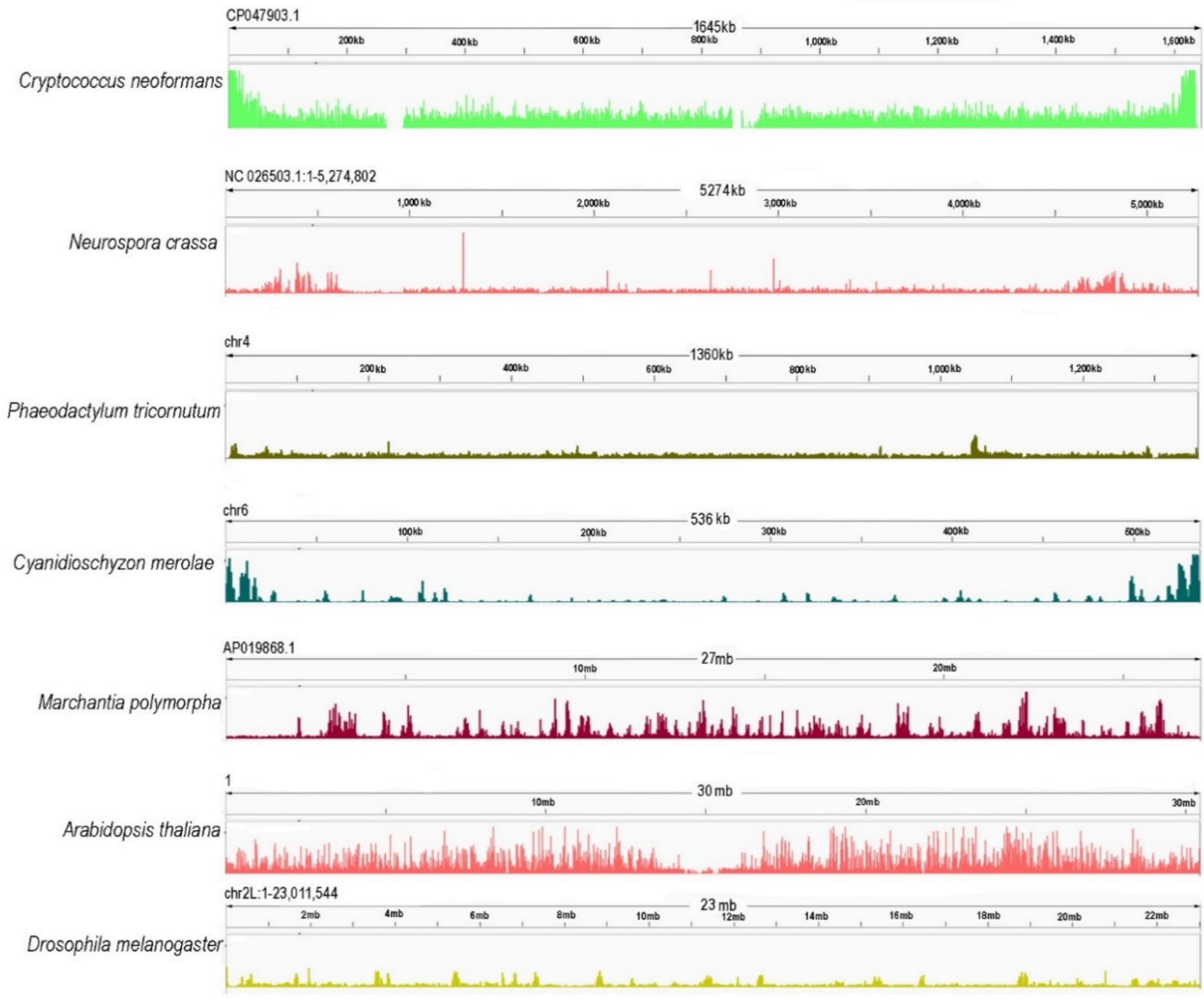

Figure 3. Chromosome-wide distribution of H3K27me3 in different model species [Cryptococcus neoformans (ASM1180120v1/PRJNA261445) [64], Neurospora crassa (NC12/PRJNA192863) [111], Phaedactylum tricornutum (ASM15095v2/PRJNA282957) [165], Cyanidioschyzon merolae (ASM9120v1/PRJNA362822) [63], Marchantia polymorpha (ASM993635v2/PRJNA553138) [166], Arabidopsis thaliana (TAIR10/PRJNA277409) [167], Drosophila melanogaster (PRJNA379297) [168]. Genome reference and accessions are given in brackets. Here, the publically available data were downloaded, cleaned by removing the library adapters, small reads (30), and low-quality (20) reads using Trim galore [169]. To map the sequenced data, Bowtie2 [170] was used with default parameters. Only mapped reads were kept with a quality threshold of 25. The filtering was performed using SAMTOOLS [171]. For the visualization of the data, IGV [172] was used, and for the parsing of the BAM files to BW files, BamCoverage-deeptools [173].

PRC2 itself lacks sequence-specific DNA-binding ability and therefore relies on accessory proteins for targeting specific loci. Several mechanisms by which PRC2 is recruited to the chromatin targets have been identified. Among these are transcription factor site-specific recruitment, interaction with RNAs, or association with chromatin features (reviewed in the work of [88]). In D. melanogaster, PRC2 is recruited to DNA targets by different transcription factors that interact with sequence motifs known as polycomb response elements (PREs) $([174,175]$, reviewed in the work of [176]). PREs in Drosophila are found in proximal promoter regions of developmental genes. They typically span about $1.5 \mathrm{~kb}$ [177] and contain numerous binding sites for a variety of DNA sequence-specific binding factors, 
such as the GTGT-motif-binding Combgap (Cg) [178], which together mediate PRC2 recruitment to target sites (reviewed in the work of [75]). Typical fly-like PREs are not found in mammals, and even though several mammalian PREs have been reported [179], they are not evolutionarily conserved. CpG islands, hypomethylated CG-rich chromatin regions of $1-2 \mathrm{~kb}$, are associated with PRC2 recruitment in mammals, where accessory subunits rather than transcription factors mediate the recruitment ([180-182], reviewed in the work of [71]). Transcription factor-bound PRE-like elements also contribute to PRC2 recruitment in A. thaliana (reviewed in the work of [5]). Following the identification of PRC2-recruiting cis elements in the promoters of the KNOX genes [183] and the LEC2 gene [184], PRE-like elements (including GAGA motif, W-box, RY motif, GCCGCC motif, telobox motif, and others) bound by transcription factors were shown to contribute to PRC2 recruitment genomewide [185]. Several transcription factors have been demonstrated to interact directly with PRC2 subunits to mediate the complex's recruitment $[144,146,183,186]$. For instance, transcriptional repressors VIVIPAROUS1/ABI3-LIKE1 (VAL1) and VAL2 or TELOMERE REPEAT-BINDING FACTORS (TRBs) physically interact with SWN and CLF to recruit PRC2 to specific sequence motifs present in the promoters of target genes $[144,146,187]$. PRC2 recruitment through interaction with trans-acting factors that recognize cis elements is thus conserved in both plant as well as animal models (reviewed in the work of [45]).

Noncoding RNAs (ncRNAs), in particular long noncoding RNAs (lncRNAs), and nascent RNAs have also been implemented in PRC2 binding and recruitment to target sites (reviewed in the work of $[188,189])$. The formation of DNA-RNA hybrid structures (R-loops) is suggested to promote PRC2 recruitment in mammalian cells [190]. R-loops have been found at a variety of polycomb target gene loci, mostly found adjacent to the promoters (reviewed in the work of [191]), and interestingly, R-loop formation was detected at about one-third of PREs in Drosophila embryos [192], suggesting conservation of the mechanism. R-loops have been shown to positively and negatively impact recruitment, and their role is discussed $[190,193]$. IncRNAs are also known to contribute to PRC2 recruitment in $A$. thaliana. For instance, COLD ASSISTED INTRONIC NONCODING RNA (COLDAIR), COOLAIR, and COLDWRAP act in repressing FLOWERING LOCUS C (FLC) transcription by H3K27me3 [194,195] and the lncRNA APOLO contributes to LHP1 recruitment, H3K27me3 enrichment, and chromatin looping at the PINOID (PID) locus that encodes a key polar auxin transport regulator [196].

Last but not least, PRC2 recruitment and activity are prevented or promoted by its interaction with the existing chromatin environment (Figure 4). Several pre-existing chromatin modifications, including H3K27ac, H3K4me3, H3K36me2/3, and cytosine methylation in CpG islands, prevent PRC2 recruitment and/or inhibit its activity ([77,180,197-200], reviewed in the work of [201]). In addition to opposing PRC2, H3K36me3 may promote H3K27me3. In mouse embryonic stem cells, Phf19, a PCL ortholog, binds to H3K36me2/H3K36me3, recruiting PRC2 and lysine demethylases to promote PRC2 activity [202]. Although biochemical evidence is limited in plants [198], H3K27me3 mainly occupies regions that are depleted for active chromatin modifications $[154,155]$. An exception to this is regions of bivalent chromatin where activating and repressive modifications co-localize to potentiate rapid change of gene transcription. In both plant and animals, the best well-described bivalent chromatin is marked by H3K27me3 and H3K4me3 ([155], reviewed in the work of [203]), but other active modifications may co-localize with H3K27me3 including H3K4me1 in Brassica napus [204], or H3K18ac in the camalexin biosynthesis genes in A. thaliana [205]. In mammals, H3K27me3 is promoted in a self-reinforcement loop. Pre-existing H3K27me3 is bound by EED, which allosterically stimulates PRC2 to methylate adjacent unmodified H3K27 and promote the spreading of H3K27me3 [87,206,207]. H3K27me3 binding activity has not been shown for the A. thaliana EED homolog FIE. Nevertheless, A. thaliana MSI1 interacts with LHP1, which binds H3K27me3, and through this may enable H3K27me3 spreading and/or post-replicative maintenance of H3K27me3 [102,208]. In addition, $\mathrm{H} 2 \mathrm{AKub}$, the catalytic product of $\mathrm{PRC} 1$, can act as a recruitment platform for PRC2 $([209,210]$, reviewed in the works of $[45,211])$. The human PRC2 cofactors JARID2 
and AEBP2 bind to H2AK119ub, triggering a positive feedback loop [77] that ensures the maintenance of transcriptional repression. In animals as well as in plants, genome-wide deposition of H3K27me3 and H2Aub seem to be partially dependent on each other. In animal models (Drosophila, mouse, and human cells), most studies suggest that H2Aub modification is independent of H3K27me3 deposition, while H3K27me3 levels are decreased upon disruption of H2Aub (reviewed in the work of [212]). In A. thaliana, H3K27me3 overlaps with H2AK121ub at a subset of loci [26]. H2Aub is more widespread than H3K27me3, and its deposition is largely independent of PRC2 activity. In contrast, H3K27me3 depends on $\mathrm{H} 2 \mathrm{Aub}$ at sites that carry both the marks, together indicating that PRC1 may be instructive for $\mathrm{H} 3 \mathrm{~K} 27 \mathrm{me} 3$ in plants rather than vice versa [26]. Recently, three different chromatin states occupied either by H3K27me3 only, H2Aub only, or both modifications were described in A. thaliana, showing that accessibility increases from the inaccessible H3K27me3-only-marked chromatin to H3K27me3/H2Aub and H2Aub-only chromatin, that are mainly located at transcriptional hotspots [213]. This is in line with findings that $\mathrm{H} 2 \mathrm{Aub}$ associates with responsive genes and its repressive function relies on $\mathrm{H} 3 \mathrm{~K} 27 \mathrm{me} 3$ deposition and that H2A deubiquitination by UBP12 and UBP13 are required for stable H3K27me3-mediated repression [12,13]. Thus, while PRC1 and PRC2 activities both contribute to decreased chromatin accessibility, H3K27me3 seems to be a major contributor to stable gene repression within inaccessible chromatin regions in $A$. thaliana.

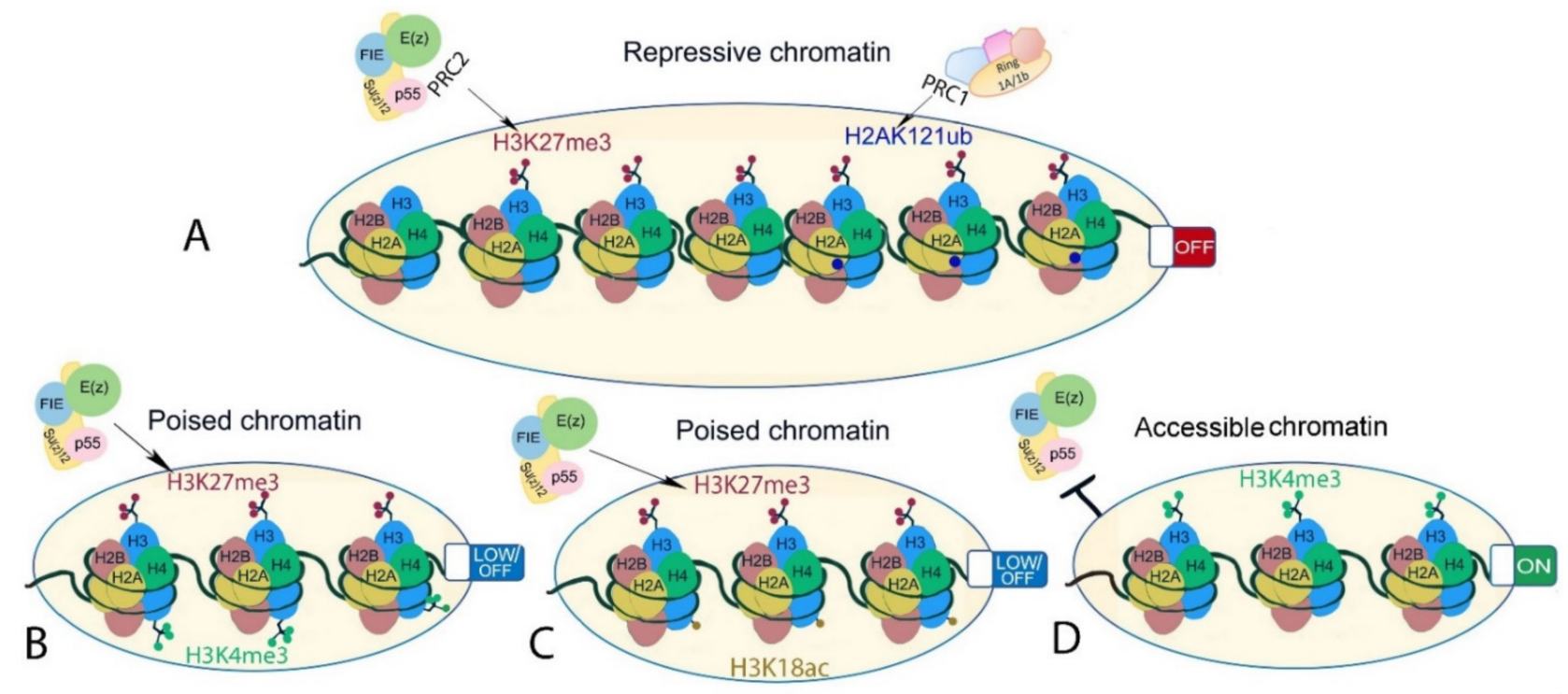

Figure 4. Different chromatin states associated or interacting with $\mathrm{H} 3 \mathrm{~K} 27 \mathrm{me} 3$ in plants. (A) Facultative heterochromatin-inaccessible H3K27me3-marked chromatin (left) and inaccessible but permissive H3K27me3- and H2AK121ub-marked chromatin (right). (B,C) bivalent chromatin is marked by histone modifications with opposing effects on gene transcription. Examples are (B) H3K27me3H3K4me3 and (C) H3K27me3 and H3K18ac. These are poised states where gene transcription is readily initiated upon stimuli. (D) Euchromatin showing chromatin state at transcriptionally active genes that is known to interfere with PRC2-mediated H3K27me3 deposition on the same histone tail in A. thaliana.

\section{PRC2 Is Conserved throughout Evolution in Unicellular and Multicellular Eukaryotes}

Despite their conservation in animal and plant multicellular model organisms, the absence of PRC2 in unicellular model organisms such as S. cerevisiae and S. pombe (reviewed in the work of $[15,214])$ and the requirement for the specification of cell identity led to the initial hypothesis that it was generally absent in unicellular models and evolved with multicellularity (reviewed in the work of $[215,216])$. Later, PRC2 subunit homologs were identified in the genomes of unicellular species of different eukaryotic supergroups, 
suggesting that PRC2 originated early in eukaryotic evolution [31,217] and could have been present already in the phylogenetically deduced putative reference biological state known as the "Last Eukaryotic Common Ancestor (LECA)" [218,219]. The absence of PRC2 in the model yeasts is currently attributed to secondary loss [31,75]. PRC2 and H3K27me3 distribution were described in the diatom Phaeodactylum tricornutum [165], the budding yeast Cryptococcus neoformans [64], and the red alga Cyanidioschyzon merolae [63], confirming PRC2 composition and functional conservation in unicellular representatives of diverse eukaryotic supergroups. The widespread presence of PRC2 subunits in unicellular species was demonstrated in an array of marine microalgae of diverse supergroups [65,103,217], further supporting the conservation and early origin of PRC2. PRC2 evolution is thought to have been shaped by genome duplication and subunit diversification, as the diversity of PRC2s tends to rise with increasing body plan complexity (Figure 1) [89,220,221]. Below, we bring a brief overview of known aspects of PRC2 function in diverse clades of eukaryotic supergroups including SAR (Stramenopila, Alveolata, Rhizaria), ciliates (Alveolata) and diatoms (Stramenopila), Ophistokonta, fungi and simple multicellular animals, red algae (Rhodophyta) and the green lineage (Viridiplantae).

\subsection{PRC2 in Stramenopiles, Alveolates and Rhizaria (SAR)}

PRC2 subunits and H3K27me3 are present in species of the SAR groups, although secondary absence may be common in the diverse taxa $[31,65,165]$. PRC2 subunits and H3K27me3 are found in Rhizaria [65,103], but no further information on PRC2 function is available in this group. Dinoflagellate (Alveolata) genome that is organized in a liquid crystalline structure [222] encodes divergent H3 variants and multiple SET domain proteins [223]. PRC2, however, seems to be absent here with the exception of the Esc homolog in Symbiodinium and Alexandrium species [103], perhaps reflecting the absence of structural nucleosomes and limited involvement of Dinoflagellate histones in heterochromatinization $[65,223,224]$. In the SAR groups, PRC2 has been best well studied in ciliates (Alveolata) and the model diatom Phaeodactylum tricornutum (Stramenopila).

Ciliates (Alveolata) are widely used in evolutionary studies because of the early evolutionary divergence [225]. Cells of ciliates contain two nuclei: the diploid germline micronucleus (MIC), which remains transcriptionally silent during vegetative growth and provides genetic material transferred to sexual progeny, and the somatic polyploid macronucleus (MAC), which provides for transcription during vegetative growth. The macronucleus genome undergoes complex rearrangements, which include small RNA ("scan" RNAscnRNA)-guided heterochromatinization and elimination of repetitive sequences (reviewed in the work of [226]). The heterochromatinization event involves deposition of $\mathrm{H} 3 \mathrm{~K} 9 \mathrm{me} 2 / 3$ and H3K27me3, RNAi, and the activity of the E(z) homolog EZL1 [227-230]. EZL1 in Tetrahymena thermophila is a component of the EZL1 complex that comprises subunits homologous to animal PRC1 as well as PRC2 subunits [107]. EZL1 complex interacts with ENHANCED MIRNA ACTIVITY 1 (EMA1), a helicase implicated in RNA interference, via scnRNA-mediated anchoring to nascent ncRNA transcripts, which is thought to be critical in EZL1 recruitment to chromatin [107]. Importantly, EZL1 in T. thermophila and Paramecium teraurelia carries out methylation of $\mathrm{H} 3 \mathrm{~K} 27$ as well as $\mathrm{H} 3 \mathrm{~K} 9$, indicating dual substrate specificity, which is likely to be conserved in ciliates [106,107]. In both ciliate models, EZL1 is required for the repression of TEs, marked by H3K9 and H3K27 methylation [106,107]. Although H3K9me3 and H3K27me3 marks are catalyzed by distinct HMTs in animal and plant models, studies in ciliates indicate that these epigenetic marks may share a common evolutionary history. Interestingly, in addition to H3K27, H3K9 was also described as a substrate for PRC2 in initial biochemical studies in Drosophila and mammals [50,231-233]. Even though this remains unresolved, it raises the possibility that under specific conditions, H3K9 may serve as a substrate in distant $\mathrm{E}(\mathrm{z})$ homologs.

Diatoms are photosynthetic secondary endosymbionts (microalgae) found throughout marine and freshwater environments. The pennate diatom Phaeodactylum tricornutum (Stramenopila) is a well-studied model species. PRC2 and H3K27me3 are conserved in 
P. tricornutum $[65,165]$. H3K27me3-marked regions cover about $14 \%$ of the P. tricornutum genome, with H3K27me3 being particularly abundant at TEs [165]. P. tricornutum has a variety of morphologies (fusiform (FM) most stable morphotype, triradiate (TM), oval (OM), and cruciform (CM)) that are determined by PRC2 and H3K27me3 [65]. Therefore, PRC2 and its associated mark $\mathrm{H} 3 \mathrm{~K} 27 \mathrm{me} 3$ are proposed to modulate cell differentiation and cell identity also in unicellular organisms [65]. This is the first evidence of H3K27me3 influencing cell morphology in a unicellular eukaryote, and this function may have been retained and/or become dominant in multicellular plants and animals. It is interesting to note, however, that in contrast to PRC2 conservation and requirement for cell identity specification in the unicellular diatom, multicellular brown algal species of the Stramenopile group (Ectocarpus siliculosus Ec32, Cladosiphon okamuranus, Nemacystus decipiens, and Saccharina japonica) lack H3K27me3 and PRC2 core subunits except p55, as well as PRC1 components [104], indicating that alternative mechanisms operate in cell identity specification in these species.

\subsection{PRC2 in Ophithokonts}

PRC2 is well studied in fungi (reviewed in the works of $[109,214,234]$ ), and reports are emerging that describe PRC2 function in simple multicellular animals [114,115]. Fungi are marked by secondary loss of PRC2 in multiple species. In fungal clades such as Schizosaccharomycetales, Saccharomycotina, and Eurotiomycetidae, PRC2 subunits seem to be absent, and H3K27 methylation is not detected in S. cerevisiae, S. pombe, and Candida albicans (reviewed in the work of [214]). H3K27me3 was first identified in the filamentous ascomycete fungus Neurospora crassa [235], and homologs of animal PRC2 subunits and H3K27me marks were identified in other ascomycete and basidiomycete species (reviewed in the work of $[68,214])$. Crystal structure of PRC2 is available for Chaetomium thermophilum, thermophilic pathogenic ascomycete [79]. CtPRC2 has structural similarities to its human equivalent, implying that fungal and animal PRC2s are structurally comparable [236]. However, substantial differences exist between metazoan and fungal PRC2 core subunits at the protein sequence level. Fungal E(z) homologs (KMT6 proteins) are longer and display limited sequence conservation outside the CXC and SET domains compared to metazoan $\mathrm{E}(\mathrm{z})$ homologs, but the sequence is conserved among fungal KMT6 proteins, supporting conservation of function and protein-protein interactions in fungi [110]. Esc/EED homologs in studied fungi are distinguished by a long "insertion domain" of unknown function near the C-terminal end, that is absent in plants and animals (reviewed in the work of [234]). SUZ12 homologs can be missing in some fungal species (e.g., C. neoformans) but can be functionally substituted by other proteins (reviewed in the work of $[109,214,234]$ ).

PRC2 is well studied in the filamentous ascomycete Neurospora crassa and the basidiomycete Cryptococcus neoformans, and H3K27me3 distribution has been studied in the ascomycetes Fusarium graminearum, F. fujikuroi, and Podospora anserina [64,110,112,237,238]. In the filamentous ascomycete Neurospora crassa, all core PRC2 subunits are found, including $\mathrm{E}(\mathrm{z})$ homolog SET-7 (KMT6), EED, SU(Z)12, and the p55 homolog NPF (Neurospora protein 55), which are all required for H3K27me3 [111]. In addition, a previously unknown PRC2 Accessory Subunit (PAS) was recently discovered, N. crassa [112]. NPF and PAS are required for H3K27 methylation in subtelomeres, but not at internal PRC2 target sites [111,112]. PAS has homologs in other fungal species, indicating that it is not unique to $N$. crassa. In a number of fungal lineages (e.g., Sordariomycetes and Leotiomycetes), PAS homologs are predicted to alter the distribution of H3K27 methylation and underlying gene repression. H3K27me3 covers around 7\% of the N. crassa genome and spans large domains, which are predominantly located in the proximity of telomeres and include hundreds of transcriptionally inactive genes [111]. H3K27me3 in telomeres resides in gene-containing regions, and it is neighbored by non-overlapping $\mathrm{H} 3 \mathrm{~K} 9 \mathrm{me} 3$ marking gene depleted, DNA-methylated regions [111,235]. Interestingly, H3K27me3-marked loci represent only a small subset of inaccessible regions of chromatin as determined by ATAC-seq, and H3K36me, rather than H3K27me3, is a predictive mark of chromatin inaccessibility in gene-rich regions in $N$. crassa [239]. 
Different extent of H3K27me3 marking is observed in other ascomycete species that have been studied $[110,237,238]$. Fusarium graminearum is an ascomycete pathogen that causes fusarium head blight in wheat and barley. H3K27me3 locates in broad domains mainly to subtelomeric regions, and it is deposited by the $\mathrm{E}(\mathrm{z})$ homolog KMT6. In contrast to $N$. crassa, about $30 \%$ of the genome is marked by $\mathrm{H} 3 \mathrm{~K} 27 \mathrm{me} 3$. About $75 \%$ of silent genes are enriched in $\mathrm{H} 3 \mathrm{~K} 27 \mathrm{me} 3$, and among these are major secondary metabolic gene clusters [110]. A similar distribution of H3K27me3 is observed in the rice pathogen Fusarium fujikuroi, where secondary metabolite clusters frequently located in subtelomeric regions are primarily targeted [237]. In the filamentous ascomycete Podospora anserina, H3K27me3 covers approximately $20 \%$ of the genome and, similarly to other ascomycetes, it is located in subtelomeric regions [238]. It is interesting to note that while deletion of KMT6, EED, or SUZ(12) in N. crassa has no visible phenotype effect [111], KMT6 dysfunction in Fusarium species and $P$. anserina results in activation of secondary metabolic genes and severe growth and developmental defects $[110,237,238]$. In P. anserina, a tight link between constitutive and facultative heterochromatin is observed. H3K27me3 is exclusive with $\mathrm{H} 3 \mathrm{~K} 9 \mathrm{me} 3$ in gene-rich regions, but the two marks overlap and are interdependent in repeats [238].

Similar H3K27me3 distribution as in N. crassa is found in the basidiomycete fungus C. neoformans. Here, H3K27me3 occupies approximately $5 \%$ of the genome and is concentrated in subtelomeres, creating broad gene-repressing domains [64]. C. neoformans PRC2 comprises a five-subunit functional core composed of an $\mathrm{E}(\mathrm{z})$ homolog, two WD40 domain proteins (Esc/EED ortholog Eed1 and p55 ortholog Msl1), and two additional subunits: Bnd1 (Big protein with no functional domains) and a coiled coil chromodomain-containing subunit Ccc1 that recognizes H3K27me3 [64]. The Su(z)12 subunit is missing in C. neoformans $[31,64,240]$, and, instead of the Su(z)12-containing lobe, the Ccc1 and Bnd1 may facilitate targeting [64]. Indeed, the absence of the Ccc1 subunit causes the redistribution of H3K27me3 into H3K9-methylated centromeric regions. The redistribution depends on the H3K9me2 HMT Clr4 and was proposed to be attributed to the latent affinity of Eed1 to HK9me2 that is potentiated upon Ccc1 depletion [64]. Ccc1 and Bnd1 are more restricted in their conservation, suggesting the presence of specific PRC2 complexes in some fungal species (reviewed in the work of [214,234]).

Despite the general presence of PRC2 in metazoans, Capsaspora owczarzaki, the closest known unicellular metazoan relative, lacks H3K27me3 marks and PRC2 complex proteins [113]. PRC2 subunit homologs and H3K27me3 are found in sponges (phylum Porifera), ancient animal species that split from other multicellular eukaryotes (metazoans) $\sim 600$ million years ago, earliest among surviving metazoan lineages ([241], reviewed in the work of [242]). PRC2 subunit homologs and H3K27me3 are conserved in the marine sponge Amphimedon queenslandica [114]. Like in Drosophila, A. queenslandica PRC2 complexes are likely to be recruited via PRE-like sequences that contain conserved binding motifs similar to GAGA and Kruppel-like motifs, as well as transcription factors similar to homeodomain-containing developmental regulators (e.g., Irx-family members), suggesting conservation of targeting and recruitment [114]. PRC2 subunits are also conserved in Hydra vulgaris, a freshwater polyp and regeneration model [115]. In H. vulgaris, the transcription factor Yin Yang 1 (YY1), a ubiquitous mammalian transcription factor that plays a crucial role in the development of the central nervous system (reviewed in the work of [243]), has an evolutionary conserved role in PRC2 recruitment for targeted gene regulation [116].

In the model nematode Caenorhabditis elegans, repressive H3K27me3 was detected on about $70 \%$ of embryonic histones, with a higher proportion of the modification located in chromosome arms [244,245]. PRC2 is conserved, with E(z) homolog MES-2 and ESC homolog MES-6. Su(z)12 homolog is missing but a C. elegans-specific core component MES3 is present [122,123,246,247]. Like the Bnd1 subunit in C. neoformans PRC2 [64], the MES-3 component lacks any specific domain or motif and appears to be unrelated to any other polycomb proteins $[57,248]$. MES-3 might have emerged in C. elegans PRC2 to substitute the function of $\mathrm{Su}(\mathrm{z}) 12$, despite the absence of sequence similarity [57]. Su(z)12 may therefore represent a dispensable component of PRC2 in some species. 


\subsection{PRC2 in Cryptophytes, Red Algae, and the Green Lineage}

PRC2 subunit homologs have been identified in cryptophytes [103] and in a number of unicellular red algae [31], but information on H3K27me3 distribution or PRC2 function remains mostly unknown. PRC2 is nevertheless studied in Cyanidioschyzon merolae [63], a red alga with a small low-repetitive genome $(16 \mathrm{Mb})$, which makes it a suitable model for studying chromatin repression in an evolutionary context [249]. In C. merolae, H3K27me3 is predominant at telomeres and the subtelomeric region of the chromosomes and has a particular preference for intein-containing genes responsible for protein splicing [63].

Homologs of the PRC2 subunits have been identified in the genomes of representative species of the green lineage, including chlorophyte algae and land plants, confirming the evolutionary conservation of the complex (Table 1, Supplementary Table S1) ([89], reviewed in the works of $[69,250])$. Still, our insight into PRC2 evolution in the green lineage is limited (reviewed in the work of [250]), and most of the current understanding of plant PRC2 composition or function comes from studies in the dicot flowering plant model Arabidopsis thaliana (reviewed in the work of $[3,18,45,47,101,251-253])$ and monocot crop species such as rice (Oryza sativa) [91,254], maize (Zea mays) [94,255], and, more recently, bread wheat (Triticum aestivum) [97]. Information on PRC2 structure and function in the green lineage outside of angiosperms is scarce; however, a recent study in Norway spruce (Picea abies) brought first insights into gymnosperm PRC2 function [92]. Conservation of PRC2 subunits in bryophytes [89] together with the determination of their developmental roles $[61,62,256]$ and recent elucidation of H3K27me3 distribution $[166,257]$ brought first insights into PRC2 function in non-vascular land plants. Studies of the chlorophyte alga Chlamydomonas reinhardtii [31] have highlighted the possible differences in PRC2 function in the green lineage.

The first PRC2 components, homologs of the $\mathrm{E}(\mathrm{z})$, were identified in A. thaliana in the late 1990s as developmental regulators and repressors of homeotic genes, revealing conservation of PRC2 between animals and plants [258,259]. PRC2-subunit genes have gone through several rounds of gene duplication and diversification. Gene duplication followed by neo-functionalization is most apparent in the evolution of PRC2 in the genomes of angiosperms $[89,91,93,94,220,260]$. E(z) homologs are found throughout the green lineage $[31,89]$, clustering into four clades, one comprising chlorophyte algae $\mathrm{E}(\mathrm{z})$ homologs and three land plant (Embryophyta) clades defined by the A. thaliana $\mathrm{E}(\mathrm{z})$ paralogs CLF, SWN and MEA [89]. CLF orthologs are most ancient, representing the only E(z) homologs in Bryophytes (Physcomitrium patens), Lycopodiophytes (Selaginella moellendorffii primitive spikemoss), or gymnosperms [91,221,261,262]. SWN orthologs are only identified in angiosperms (both in monocots and dicots). SWN is already found in the basal angiosperm species Amborella trichopoda, suggesting that SWN could have emerged with the separation of angiosperms and gymnosperms [92,261]. MEA is a shorter paralog of SWN that originated by duplication of SWN during the $\alpha$ whole-genome duplication ( $\alpha$ WGD) and neofunctionalization in Brassicaceae $[89,91,220,221]$. Likewise, $\mathrm{Su}(\mathrm{z}) 12$ homologs are found throughout the green lineage $[89,90]$ with putative loss in S. moellendorffii and Volvox carteri $[31,89]$. Su(z) 12 homolog found in the chlorophyte alga C. reinhardtii forms a separate clade from homologs in land plants. In land plants, EMF2 homologs are the most ancient and are found in non-vascular plants as well as in seed plants [90]. VRN2 homologs have only been reported in flowering plants so far, and VRN2 is hypothesized to have evolved through the duplication of an ancestral EMF2-like gene [90,221]. FIS2 is found only in Brassicaceae, where it emerged with the $\alpha$ WGD by duplication of VRN2 [89-91,221]. VRN2 has an oxygen-sensitive degradation sequence (N-degron) at its $\mathrm{N}$-terminus, and its degradation decreases (and abundance increases) in hypoxic and cold environments, implying that VRN2 N-degron plays a role in environmental adaptation [263]. The presence of proteolysis-initiating methionine-cysteine (MC) dipeptide in the N-terminus in all the studied VRN2 homologs across angiosperms, including monocots, and its absence in the $\mathrm{Su}(\mathrm{z}) 12$ homologs of basal land plants or mammals, suggests that $\mathrm{O} 2$-sensitive $\mathrm{Su}(\mathrm{z}) 12$ proteins are solely present in angiosperms [263]. In multiple angiosperms, including Am- 
borella trichopoda, but not basal land plants (lycophytes and bryophytes), EMF2 contains internally located MC-dipeptide not subject to N-end rule degradation, supporting VRN2 origin by EMF2 duplication and N-terminal truncation [263]. The Esc homolog FIE is highly conserved throughout the green lineage, suggesting an ancient role within the PRC2 [31,89]. In contrast to dicot species that contain a single FIE copy, monocots including rice, maize, and sorghum have two Esc homologs [91]. The single chromosomal location of FIE genes in rice and sorghum indicates that the two homologs evolved via a tandem duplication event [91]. Several FIE subunit paralogs with distinct chromosomal positions have been identified in bread wheat, which could be attributed to the allohexaploid nature of the genome [97]. A direct interaction between Esc and $\mathrm{E}(\mathrm{z})$ homologs has been demonstrated in $A$. thaliana $[220,264]$ and based on structural conservation, Esc homologs may interact with other PRC2-core subunits in a manner similar to that of Drosophila and mammals (reviewed in the work of [45]). Finally, the p55 homologs MSI1-5 are substantially conserved across the green lineage, forming three distinct clades in phylogram, separating MSI1, MSI2 and MSI3, and MSI4 and MSI5 [132]. Among them, PRC2-core subunit MSI1 is conserved in chlorophyte algae as well as in land plants $[69,89]$.

In angiosperms, many genome-wide histone modification studies have been conducted using Brassicaceae species or crops (e.g., maize, rice, barley, and wheat) [38,265-268]. Similar to A. thaliana, about one-third of protein-coding genes were identified as H3K27me3 targets in Brassica rapa, including key flowering genes [269]. Similar genomic distribution of H3K27me3 is also seen in monocots, including maize (Zea mays), rice (Oryza sativa), or Brachypodium distachyon [265,267,270,271]. In gymnosperms, H3K27me3 distribution has been studied cytologically [272] and also genome-wide in P. abies [92]. H3K27me3 was identified to be consistently located in the mid-arm areas of almost all chromosomes in Pinus sylvestris and Norway spruce, which is comparable to other angiosperms [272]. In Norway spruce, H3K27me3 plays a crucial role in embryogenesis, suggesting a conserved role of PRC2 in cell fate determination [92]. H3K27me3 distribution in the moss $P$. patens [257] and in the liverwort Marchantia polymorpha [166] brought important insights into the targeting of PRC2 in bryophytes. In the protonema and gametophore of P. patens, H3K27me3 localizes around the transcription start sites (TSS), covering the promoter region and spreading into the gene bodies [257]. In this respect, the distribution of H3K27me3 in P. patens seems similar as in A. thaliana, which, however, contrasts with the situation in M. polymorpha. Here, H3K27me3 occupies 30\% of constitutive heterochromatin, forming a chromatin state distinct from constitutive heterochromatin occupied jointly by H3K27me1, H3K9me1, and DNA methylation [166]. Unlike in other land plants, H3K27me3 in M. polymorpha is distributed in broad domains that overlay inactive genes and surrounding repeats or transposons. As identified by $\mathrm{Hi}-\mathrm{C}$, these genomic sites also represent trans-interacting regions within the B-compartment, and PRC2 was proposed to function in heterochromatin organization in M. polymorpha [166]. In addition to H3K27me3, H2Aub distribution was recently studied in $M$. polymorpha. H2Aub localizes mainly to gene bodies and promoter regions, where it is required for the recruitment of H3K27me3. At a subset of TE's, H2Aub is connected to H3K27me3 enrichment, and its absence leads to H3K27me3 depletion [273], suggesting similar inter-dependence, such as in $A$. thaliana. In bryophytes, unlike in $A$. thaliana [155], TEs and constitutive heterochromatin modifications such as H3K9me1/2, H3K27me1 do not concentrate in centromeric and pericentromeric regions but are rather dispersed throughout the genome $[166,274]$. Despite this similarity in the repetitive genome organization, the distribution of H3K27me3 in P. patens and in M. polymorpha seems to differ. It will be of great interest to identify the differences between the PRC2 complexes in these species that now seem to stand at the breakpoint of PRC2 function evolution. The distribution of H3K27me in chlorophyte and streptophyte algae still remains enigmatic. An early study reported H3K27 mono-methylation (H3K27me) in the unicellular green alga C. reinhardtii [275]. Later mass spectrometry analyses in C. reinhardtii showed that histone H3 lysine 27 (H3K27) can be mono- or di-methylated, but H3K27 trimethylation was not confirmed and suggested to be either absent or present at significantly low levels [31]. 
Enrichment of H3K27me3 in C. reinhardtii appeared to be very low in a ChIP-seq study, where inter- and intragenic distribution of H3K27me3 was suggested [276]. Despite the uncertainties as to H3K27me3 presence, homologs of E(z), EMF2, FIE, and p55/MSI1 have been identified in silico in the C. reinhardtii genome [31,89]. Since homologs of ATXR5 or ATXR6 were not found in $\mathrm{C}$. reinhardtii. $\mathrm{CrE}(\mathrm{z})$ may be hypothetically responsible for the mono- and di-methylation of H3K27 [31]. RNAi-mediated suppression of C. reinhardtii $\mathrm{E}(\mathrm{z})$ resulted in ectopic upregulation of repetitive transgenes and retrotransposons, providing the first evidence for PRC2 function in repressing genomic repeats in unicellular eukaryotes [31]. Notably, loss of H3K27me1 in A. thaliana atxr5 atxr6 mutant also results in the reactivation of heterochromatic transposable elements [150]. Whether reactivation of repetitive elements in C. reinhardtii is primarily connected to the loss of $\mathrm{H} 3 \mathrm{~K} 27 \mathrm{me} 3$ or H3K27me1/2 remains unclear.

Based on the currently available information, the predominating function of PRC2 in the green lineage seems to have shifted during evolution from the organization of constitutive heterochromatin (C. reinhardtii and M. polymorpha) to facultative repression of genes that respond to the internal and external cues (P. patens, angiosperms). In P. patens $[61,62,256]$ as well as in flowering plants (reviewed in the work of [47,48,251,252]), PRC2 is required for correct timing and execution of developmental phase transitions. In particular, the alternation between sporophyte and gametophyte and repression of apogamy depends on PRC2 in A. thaliana [277-279] as well as P. patens [256], demonstrating an evolutionarily conserved role of the complex. In accordance, developmental genes in both $A$. thaliana (reviewed in the work of $[47,48,251,252]$ ) and P. patens [257] undergo H3K27me3 remodeling during developmental phase transitions. In A. thaliana, response to salt stress and nitrate or iron deficiency is modulated by PRC2 [158-160], implicating PRC2 in environmental response. In P. patens, drought stress was not associated with changes in H3K27me3 distribution [257], suggesting a limited impact of PRC2 in this response. Evolutionary conservation of PRC2 involvement in environmental responses needs to be determined. Interestingly, orthologous genes involved in metabolism and stress response in Brassicaceae species separated by limited evolutionary distance display concordant H3K27me3 marking [161], suggesting conservation of PRC2 involvement in transcriptional regulation of these genes. On the other hand, orthologs involved in developmental functions display higher concordance of H3K27me3 marking in species separated by larger evolutionary distances [161]. This may suggest that developmental modulation by PRC2 is more conserved in evolution, at least within species of certain (limited) evolutionary distance, or that it is less dynamic compared to environmental response regulation and therefore more easily detected.

\section{PRC2 Targeting to Repeats and Regions of Constitutive Heterochromatin}

In mammals and flowering plants in wild-type conditions, H3K27me3 marks chromatin domains of facultative heterochromatin that are distinct from those of constitutive heterochromatin marked by H3K9 methylation (H3K9me) and/or DNA methylation ([154,155,280], reviewed in the works of $[9,281])$. Increasing evidence nevertheless points to the interplay between mechanisms establishing H3K27me3- and H3K9me/DNAme-marked chromatin in eukaryotes (Table S2) (reviewed in the work of $[9,49]$ ). First, H3K27me3 is found to be targeted to TEs in wild-type situations in several unicellular species, including the diatom Phaeodactylum tricornutum [165], the red alga C. merolae [63], or the ciliate Paramecium tetraurelia [106], but also in multicellular species, such as the bryophyte M. polymorpha [166] or even A. thaliana [282]. Second, in some fungi, H3K27me3 may co-occur with H3K9me [64,238]. Third, H3K27me3 is redistributed to constitutive heterochromatin including TEs upon disruption of H3K9me or DNA hypomethylation in mammals [283-285], upon developmental or induced DNA hypomethylation in Arabidopsis [286-290], or upon loss of H3K9me or its reader HETEROCHROMATIN PROTEIN 1 (HP1) in Neurospora crassa [291,292] or the pathogenic fungus Zymoseptoria tritici [293]. Fourth, disruption of PRC2 can lead to transcriptional activation of TEs in mouse ES cells [294], in ciliates [106,230], or in the green alga Chlamydomonas reinhardtii [31]. These pieces of evidence led to the proposal 
of an ancestral role of PRC2 in repressing transposable elements (reviewed in the work of [49]). However, the contribution of PRC2 to TE silencing may be limited to some TE families [282], as its absence does not aggravate TE de-repression in A. thaliana hypomethylated tissues $[289,290]$. Intriguingly, in $A$. thaliana, the absence of CLF in hypomethylated $d d m 1$ mutant even promotes DNA re-methylation and chromatin recompaction, suggesting a more intricate interplay between the two silencing pathways [276].

In addition to $\mathrm{H} 3 \mathrm{~K} 9 \mathrm{me} / \mathrm{DNA}$ methylation-associated constitutive heterochromatic regions, emerging reports describe targeting of $\mathrm{H} 3 \mathrm{~K} 27 \mathrm{me} 3$ to telomeric repeats in different genera and even different eukaryotic supergroups. H3K27me3 is frequently enriched in telomeric and subtelomeric regions in ascomycete and basidiomycete fungi (reviewed in the work of [68]) and contributes to telomere clustering at the nuclear periphery in N. crassa [295]. H3K27me3 has been found in telomeres in mammals [296] as well as plants [297,298]. In human cell lines, PRC2 is recruited to telomeres via interaction with telomeric repeat-containing RNAs (TERRAs) [296], lncRNAs originating from the telomeres that contribute to telomere homeostasis and telomeric heterochromatin formation (reviewed in the work of [299]). Interestingly, PRC2 at telomeres is required for H3K9me3, H3K20me3, and HP1 binding [296], suggesting an instrumental role of PRC2 in the establishment of heterochromatin at human telomeres. Noncoding telomeric RNAs are also generated from the (sub)telomeric regions in plants [297,300], and it will be interesting to determine their potential contribution to PRC2 recruitment in plants. In addition to telomeric PRC2 targeting, TERRAs together with TRF1 (telomeric repeat-binding factor 1), a component of the telomere protective complex shelterin (reviewed in the work of [301]), target H3K27me3 to the vicinity of genes involved in pluripotency and developmental control, suggesting conservation of these recruitment mechanisms outside of telomeres [302]. Similarly, in A. thaliana, the plant telomere-associated protective components TELOMERE REPEAT BINDING proteins (TRB's) ([303], reviewed in the work of [304]) interact with PRC2 subunits CLF and SWN, recruiting PRC2 to telobox motifs of H3K27me3-targeted genes [144,305]. Telobox is independently identified among motifs that mediate PRC2 targeting in $A$. thaliana [185], suggesting a more general role of telomeric repeats in genomewide recruitment of plant PRC2. In N. crassa, interstitial telomeric sequence motifs can also initiate ectopic H3K27me3 recruitment and spread into broad domains surrounding the recruitment site [306], suggesting the instructive role of telomeric repeats in PRC2 targeting also in fungi. Targeting of PRC2 to telomeric repeats therefore appears to be conserved in evolution. As TEs that are targeted by PRC2 in the absence of DNA methylation also frequently contain telobox motifs [290], it remains a question whether PRC2 recruitment to telobox motifs in genes is a remnant of ancestral TE targeting or whether ancestral telobox targeting contributed to recruitment to genes and TEs.

\section{Emerging Patterns and Questions in PRC2 Evolution}

Recent work has demonstrated the early emergence of PRC2, its presence, and its fundamental functions in unicellular as well as multicellular eukaryotes, but also secondary loss in some species. Mechanisms that contribute to the dispensability of PRC2 in these species will be interesting to elucidate. The core composition of PRC2 seems to be well conserved in eukaryotic evolution, mainly involving E(z), Esc, and p55, while Su(z)12 function may be dispensable or substituted by other proteins in some species. Compositional diversity may therefore underlie the functional conservation of PRC2. Although PRC2 subunits are predicted to be encoded in the genomes of numerous eukaryotic species, biochemical evidence for their presence and function is lacking. Accessory subunits are known to influence PRC2 recruitment or function and even define different PRC2 complexes, but information about them in different species is very limited. Similarly, only partial understanding of the functional crosstalk between PRC2 and PRC1 exists outside of mammalian models, despite the vital contribution of PRC1 to PRC2 repression. Continued efforts in elucidating aspects of PRC2 composition, subunit interaction, catalytical function, 
genomic targeting, and dynamics of polycomb-modified chromatin in different species will be crucial for understanding its evolution.

Increasing evidence suggests the ancestral function of PRC2 in facultative heterochromatin organization [49]. A pattern seems to be emerging of H3K27me3 targeting repetitive genomic elements in simple eukaryotes, while gene-specific targeting seems to prevail in complex eukaryotic species. However, how the H3K27me3-catalytic function of PRC2 within facultative heterochromatin in genic regions evolved remains unknown. Several non-exclusive mechanisms can be envisaged, including changes in PRC2 catalytic activity or its genomic targeting. Dual H3K9me and H3K27me activities of E(z)-like proteins in ciliates [106], DNA methylation and/or H3K9me preventing H3K27me3 targeting to TEs in various eukaryotes [49] and recently reported prevention of H3K27me3 targeting to telomeric sequences by histone $\mathrm{H} 1$ in A. thaliana [307] may provide important hints.

The conserved function of PRC2 in cell identity specification and developmental phase transitions has been established in multicellular model species from different eukaryotic supergroups. PRC2 requirement for morphotype specification in the diatom P. tricornutum suggests that its role in cell identity specification may be conserved also in unicellular species [103]. Emerging reports associate PRC2 function with environmental response in multicellular species $[5,308]$ and also with responses to nutrition availability in diverse protists [103]. PRC2 function in dynamic environmental and metabolic responses may therefore be conserved, but further work is needed to determine the involvement of PRC2 subcomplexes and their mode of operation.

Despite recent advances, reports on the composition, biochemical activity, and targeting of PRC2 and on consequences of its dysfunction in unicellular and simple multicellular species are scarce and will be needed to allow more general conclusions as to the evolution of PRC2. PRC2 evolution must be explored in early eukaryotic and monophyletic lineages, including organisms with increasing body plan complexity. Although the green eukaryotic lineage provides a suitable model system for studying PRC2 evolution, our knowledge of PRC2 outside of angiosperms is limited. Recent studies have illuminated exciting differences in H3K27me3 targeting within the bryophyte basal land plant models, but currently, very little is known about PRC2 in green algae. Due to the limited genome availability, PRC2 has been studied only in several chlorophyte algae genera (Chlamydomonas, Volvox, and Ostreococcus), but no streptophyte algae, and further work will be needed to bring more resolution into the PRC2 subunit phylogeny reconstruction. Based on the phylogenetic separation of the PRC2 subunit homologs in the green algae and land plants and the potential loss of $\mathrm{Su}(\mathrm{z}) 12$ in some of the species [31,89], it will be interesting to determine the variations in the complex characteristics throughout the green lineage.

Supplementary Materials: Supplementary Tables are available online at https:/ /www.mdpi.com/ article/10.3390/epigenomes6010003/s1, Table S1: PRC2 core components in different species, Table S2: A general overview of the distribution of histone methylation marks (H3K27me3) and its putative functions across various species.

Author Contributions: M.V. and I.M. wrote the manuscript. M.G.T.-A. contributed to Figures 1 and 3, tables, and critically read the article. All authors have read and agreed to the published version of the manuscript.

Funding: This work was supported by the Czech Academy of Sciences ERC-CZ program (ERC200961901).

Institutional Review Board Statement: Not applicable.

Informed Consent Statement: Not applicable.

Data Availability Statement: Not applicable.

Acknowledgments: We would like to thank Armine Asatryan for collecting articles and initializing the supplementary table draft, and the three reviewers for valuable comments that improved the manuscript. Computational resources were supplied by the project "e-Infrastruktura CZ" (e-INFRA CZ LM2018140), supported by the Ministry of Education, Youth and Sports of the Czech Republic. 
Conflicts of Interest: The authors declare no conflict of interest.

\section{References}

1. Prezioso, C.; Orlando, V. Polycomb Proteins in Mammalian Cell Differentiation and Plasticity. FEBS Lett. 2011, 585, 2067-2077. [CrossRef] [PubMed]

2. Aranda, S.; Mas, G.; Di Croce, L. Regulation of Gene Transcription by Polycomb Proteins. Sci. Adv. 2015, 1, e1500737. [CrossRef]

3. Mozgova, I.; Hennig, L. The Polycomb Group Protein Regulatory Network. Annu. Rev. Plant Biol. 2015. [CrossRef]

4. Yu, J.R.; Lee, C.H.; Oksuz, O.; Stafford, J.M.; Reinberg, D. PRC2 Is High Maintenance. Genes Dev. 2019, 33, 903-935. [CrossRef] [PubMed]

5. Shen, Q.; Lin, Y.; Li, Y.; Wang, G. Plants Dynamics of H3K27me3 Modification on Plant Adaptation to Environmental Cues. Plants 2021, 10, 1165. [CrossRef]

6. Lee, H.-G.; Kahn, T.G.; Simcox, A.; Schwartz, Y.B.; Pirrotta, V. Genome-Wide Activities of Polycomb Complexes Control Pervasive Transcription. Genome Res. 2015, 25, 1170-1181. [CrossRef]

7. Bratzel, F.; López-Torrejón, G.; Koch, M.; Del Pozo, J.C.; Calonje, M. Keeping Cell Identity in Arabidopsis Requires PRC1 RING-Finger Homologs That Catalyze H2A Monoubiquitination. Curr. Biol. 2010, 20, 1853-1859. [CrossRef] [PubMed]

8. Wang, H.; Wang, L.; Erdjument-Bromage, H.; Vidal, M.; Tempst, P.; Jones, R.S.; Zhang, Y. Role of Histone H2A Ubiquitination in Polycomb Silencing. Nature 2004, 431, 873-878. [CrossRef] [PubMed]

9. Wiles, E.T.; Selker, E.U. H3K27 Methylation: A Promiscuous Repressive Chromatin Mark. Curr. Opin. Genet. Dev. 2017, 43, 31-37. [CrossRef] [PubMed]

10. Chittock, E.C.; Latwiel, S.; Miller, T.C.R.; Müller, C.W. Molecular Architecture of Polycomb Repressive Complexes. Biochem. Soc. Trans. 2017, 45, 193-205. [CrossRef] [PubMed]

11. Reddington, C.J.; Fellner, M.; Burgess, A.E.; Mace, P.D. Molecular Regulation of the Polycomb Repressive-Deubiquitinase. Int. J Mol. Sci. 2020, 21, 7837. [CrossRef] [PubMed]

12. Derkacheva, M.; Liu, S.; Figueiredo, D.D.; Gentry, M.; Mozgova, I.; Nanni, P.; Tang, M.; Mannervik, M.; Köhler, C.; Hennig, L. H2A Deubiquitinases UBP12/13 Are Part of the Arabidopsis Polycomb Group Protein System. Nat. Plants 2016, 2, 16126. [CrossRef]

13. Kralemann, L.E.M.; Liu, S.; Trejo-Arellano, M.S.; Muñoz-Viana, R.; Köhler, C.; Hennig, L. Removal of H2Aub1 by UbiquitinSpecific Proteases 12 and 13 Is Required for Stable Polycomb-Mediated Gene Repression in Arabidopsis. Genome Biol. 2020, 21, 144. [CrossRef]

14. Klymenko, T.; Papp, B.; Fischle, W.; Köcher, T.; Schelder, M.; Fritsch, C.; Wild, B.; Wilm, M.; Müller, J. A Polycomb Group Protein Complex with Sequence-Specific DNA-Binding and Selective Methyl-Lysine-Binding Activities. Genes Dev. 2006, 20, 1110-1122. [CrossRef] [PubMed]

15. Schuettengruber, B.; Bourbon, H.M.; Di Croce, L.; Cavalli, G. Genome Regulation by Polycomb and Trithorax: 70 Years and Counting. Cell 2017, 171, 34-57. [CrossRef] [PubMed]

16. Stewart-Morgan, K.R.; Petryk, N.; Groth, A. Chromatin Replication and Epigenetic Cell Memory. Nat. Cell Biol. 2020, $22,361-371$. [CrossRef] [PubMed]

17. Probst, A.V.; Desvoyes, B.; Gutierrez, C. Similar yet Critically Different: The Distribution, Dynamics and Function of Histone Variants. J. Exp. Bot. 2020, 71, 5191-5204. [CrossRef] [PubMed]

18. Hugues, A.; Jacobs, C.S.; Roudier, F. Mitotic Inheritance of PRC2-Mediated Silencing: Mechanistic Insights and Developmental Perspectives. Front. Plant Sci. 2020, 11, 262. [CrossRef]

19. Pu, L.; Sung, Z.R. PcG and TrxG in Plants-Friends or Foes. Trends Genet. 2015, 31, 252-262. [CrossRef] [PubMed]

20. Wang, S.; Ordonez-Rubiano, S.C.; Dhiman, A.; Jiao, G.; Strohmier, B.P.; Krusemark, C.J.; Dykhuizen, E.C. Polycomb Group Proteins in Cancer: Multifaceted Functions and Strategies for Modulation. NAR Cancer 2021, 3, zcab039. [CrossRef] [PubMed]

21. Dockerill, M.; Gregson, C.; O' Donovan, D.H. Targeting PRC2 for the Treatment of Cancer: An Updated Patent Review (2016-2020). Expert Opin. Ther. Pat. 2021, 31, 119-135. [CrossRef] [PubMed]

22. Piunti, A.; Shilatifard, A. The Roles of Polycomb Repressive Complexes in Mammalian Development and Cancer. Nat. Rev. Mol. Cell Biol. 2021, 22, 326-345. [CrossRef]

23. Lewis, P.H. New Mutants Report. Drosoph. Inf. Serv. 1947, 21, 69.

24. Sanchez-Pulido, L.; Devos, D.; Sung, Z.R.; Calonje, M. RAWUL: A New Ubiquitin-like Domain in PRC1 Ring Finger Proteins That Unveils Putative Plant and Worm PRC1 Orthologs. BMC Genom. 2008, 9, 308. [CrossRef] [PubMed]

25. Chen, D.; Molitor, A.; Liu, C.; Shen, W.H. The Arabidopsis PRC1-like Ring-Finger Proteins Are Necessary for Repression of Embryonic Traits during Vegetative Growth. Cell Res. 2010, 20, 1332-1344. [CrossRef] [PubMed]

26. Zhou, Y.; Romero-Campero, F.J.; Gómez-Zambrano, Á.; Turck, F.; Calonje, M. H2A Monoubiquitination in Arabidopsis Thaliana Is Generally Independent of LHP1 and PRC2 Activity. Genome Biol. 2017, 18, 69. [CrossRef] [PubMed]

27. Berke, L.; Snel, B. The Plant Polycomb Repressive Complex 1 (PRC1) Existed in the Ancestor of Seed Plants and Has a Complex Duplication History. BMC Evol. Biol. 2015, 15, 44. [CrossRef] [PubMed]

28. Chen, D.; Huang, Y.; Ruan, Y.; Shen, W.-H. The Evolutionary Landscape of PRC1 Core Components in Green Lineage. Planta 2016, 243, 825-846. [CrossRef] [PubMed]

29. Hennig, L.; Derkacheva, M. Diversity of Polycomb Group Complexes in Plants: Same Rules, Different Players? Trends Genet. 2009, 25, 414-423. [CrossRef] 
30. Calonje, M. Prc1 Marks the Difference in Plant Pcg Repression. Mol. Plant 2014, 7, 459-471. [CrossRef]

31. Shaver, S.; Casas-Mollano, J.A.; Cerny, R.L.; Cerutti, H. Origin of the Polycomb Repressive Complex 2 and Gene Silencing by an $\mathrm{E}(\mathrm{z})$ Homolog in the Unicellular Alga Chlamydomonas. Epigenetics 2010, 5, 301-312. [CrossRef]

32. Sowpati, D.T.; Ramamoorthy, S.; Mishra, R.K. Expansion of the Polycomb System and Evolution of Complexity. Mech. Dev. 2015, 138, 97-112. [CrossRef]

33. Förderer, A.; Zhou, Y.; Turck, F. The Age of Multiplexity: Recruitment and Interactions of Polycomb Complexes in Plants. Curr. Opin. Plant Biol. 2016, 29, 169-178. [CrossRef] [PubMed]

34. van Mierlo, G.; Veenstra, G.J.C.; Vermeulen, M.; Marks, H. The Complexity of PRC2 Subcomplexes. Trends Cell Biol. 2019, 29, 660-671. [CrossRef] [PubMed]

35. Miller, S.A.; Damle, M.; Kim, J.; Kingston, R.E. Full Methylation of H3K27 by PRC2 Is Dispensable for Initial Embryoid Body Formation but Required to Maintain Differentiated Cell Identity. Development 2021, 148, dev196329. [CrossRef] [PubMed]

36. Mozgová, I.; Muñoz-Viana, R.; Hennig, L. PRC2 Represses Hormone-Induced Somatic Embryogenesis in Vegetative Tissue of Arabidopsis Thaliana. PLoS Genet. 2017, 13, e1006562. [CrossRef] [PubMed]

37. Turck, F.; Roudier, F.; Farrona, S.; Martin-Magniette, M.L.; Guillaume, E.; Buisine, N.; Gagnot, S.; Martienssen, R.A.; Coupland, G.; Colot, V. Arabidopsis TFL2/LHP1 Specifically Associates with Genes Marked by Trimethylation of Histone H3 Lysine 27. PLoS Genet. 2007, 3, e86. [CrossRef]

38. Zhang, X.; Clarenz, O.; Cokus, S.; Bernatavichute, Y.V.; Pellegrini, M.; Goodrich, J.; Jacobsen, S.E. Whole-Genome Analysis of Histone H3 Lysine 27 Trimethylation in Arabidopsis. PLoS Biol. 2007, 5, e129. [CrossRef]

39. Margueron, R.; Trojer, P.; Reinberg, D. The Key to Development: Interpreting the Histone Code? Curr. Opin. Genet. Dev. 2005, 15, 163-176. [CrossRef] [PubMed]

40. Steffen, P.A.; Ringrose, L. What Are Memories Made of? How Polycomb and Trithorax Proteins Mediate Epigenetic Memory. Nat. Rev. Mol. Cell Biol. 2014, 15, 340-356. [CrossRef]

41. Kang, S.J.; Chun, T. Structural Heterogeneity of the Mammalian Polycomb Repressor Complex in Immune Regulation. Exp. Mol. Med. 2020, 52, 1004-1015. [CrossRef]

42. Martin, C.J.; Moorehead, R.A. Polycomb Repressor Complex 2 Function in Breast Cancer (Review). Int. J. Oncol. 2020, 57, 1085-1094. [CrossRef] [PubMed]

43. Cao, Y.; Li, L.; Fan, Z. The Role and Mechanisms of Polycomb Repressive Complex 2 on the Regulation of Osteogenic and Neurogenic Differentiation of Stem Cells. Cell Prolif. 2021, 54, e13032. [CrossRef] [PubMed]

44. Guo, Y.; Zhao, S.; Wang, G.G. Polycomb Gene Silencing Mechanisms: PRC2 Chromatin Targeting, H3K27me3 “Readout”, and Phase Separation-Based Compaction. Trends Genet. 2021, 37, 547-565. [CrossRef] [PubMed]

45. Bieluszewski, T.; Xiao, J.; Yang, Y.; Wagner, D. PRC2 Activity, Recruitment, and Silencing: A Comparative Perspective. Trends Plant Sci. 2021, 26, 1186-1198. [CrossRef] [PubMed]

46. Glancy, E.; Ciferri, C.; Bracken, A.P. Structural Basis for PRC2 Engagement with Chromatin. Curr. Opin. Struct. Biol. 2021, 67, 135-144. [CrossRef] [PubMed]

47. Shu, J.; Chen, C.; Li, C.; Cui, Y. The Complexity of PRC2 Catalysts CLF and SWN in Plants. Biochem. Soc. Trans. 2020, 48, 2779-2789. [CrossRef] [PubMed]

48. Hinsch, V.; Adkins, S.; Manuela, D.; Xu, M. Post-Embryonic Phase Transitions Mediated by Polycomb Repressive Complexes in Plants. Int. J. Mol. Sci. 2021, 22, 7533. [CrossRef] [PubMed]

49. Déléris, A.; Berger, F.; Duharcourt, S. Role of Polycomb in the Control of Transposable Elements. Trends Genet. 2021, 37, 882-889. [CrossRef]

50. Müller, J.; Hart, C.M.; Francis, N.J.; Vargas, M.L.; Sengupta, A.; Wild, B.; Miller, E.L.; O'Connor, M.B.; Kingston, R.E.; Simon, J.A. Histone Methyltransferase Activity of a Drosophila Polycomb Group Repressor Complex. Cell 2002, 111, 197-208. [CrossRef]

51. Yang, Y.; Li, G. Post-Translational Modifications of PRC2: Signals Directing Its Activity. Epigenet. Chromatin 2020, 13, 47. [CrossRef] [PubMed]

52. Nekrasov, M.; Wild, B.; Müller, J. Nucleosome Binding and Histone Methyltransferase Activity of Drosophila PRC2. EMBO Rep. 2005, 6, 348-353. [CrossRef] [PubMed]

53. Wang, X.; Paucek, R.D.; Gooding, A.R.; Brown, Z.Z.; Eva, J.; Muir, T.W.; Cech, T.R. Molecular Analysis of PRC2 Recruitment to DNA in Chromatin and Its Inhibition by RNA. Nat. Struct. Mol. Biol. 2017, 24, 1028-1038. [CrossRef] [PubMed]

54. Wang, X.; Goodrich, K.J.; Gooding, A.R.; Youmans, D.T.; Cech, T.R.; Wang, X.; Goodrich, K.J.; Gooding, A.R.; Naeem, H.; Archer, S.; et al. Targeting of Polycomb Repressive Complex 2 to RNA by Short Repeats of Consecutive Guanines Article Targeting of Polycomb Repressive Complex 2 to RNA by Short Repeats of Consecutive Guanines. Mol. Cell 2017, 65, 1056-1067. [CrossRef] [PubMed]

55. Kasinath, V.; Poepsel, S.; Nogales, E. Recent Structural Insights into PRC2 Regulation and Substrate Binding. Biochemistry 2019, 58, 346-354. [CrossRef]

56. Holoch, D.; Margueron, R. Mechanisms Regulating PRC2 Recruitment and Enzymatic Activity. Trends Biochem. Sci. 2017, 42, 531-542. [CrossRef] [PubMed]

57. Ketel, C.S.; Andersen, E.F.; Vargas, M.L.; Suh, J.; Strome, S.; Simon, J.A. Subunit Contributions to Histone Methyltransferase Activities of Fly and Worm Polycomb Group Complexes. Mol. Cell. Biol. 2005, 25, 6857-6868. [CrossRef] [PubMed] 
58. Cao, R.; Zhang, Y. SUZ12 Is Required for Both the Histone Methyltransferase Activity and the Silencing Function of the EED-EZH2 Complex. Mol. Cell 2004, 15, 57-67. [CrossRef]

59. Pasini, D.; Bracken, A.P.; Jensen, M.R.; Denchi, E.L.; Helin, K. Suz12 Is Essential for Mouse Development and for EZH2 Histone Methyltransferase Activity. EMBO J. 2004, 23, 4061-4071. [CrossRef]

60. Kasinath, V.; Faini, M.; Poepsel, S.; Reif, D.; Feng, X.A.; Stjepanovic, G.; Aebersold, R.; Nogales, E. Structures of Human PRC2 with Its Cofactors AEBP2 and JARID2. Science 2018, 359, 940-944. [CrossRef]

61. Mosquna, A.; Katz, A.; Decker, E.L.; Rensing, S.A.; Reski, R.; Ohad, N. Regulation of Stem Cell Maintenance by the Polycomb Protein FIE Has Been Conserved during Land Plant Evolution. Development 2009, 136, 2433-2444. [CrossRef] [PubMed]

62. Okano, Y.; Aono, N.; Hiwatashi, Y.; Murata, T.; Nishiyama, T.; Ishikawa, T.; Kubo, M.; Hasebe, M. A Polycomb Repressive Complex 2 Gene Regulates Apogamy and Gives Evolutionary Insights into Early Land Plant Evolution. Proc. Natl. Acad. Sci. USA 2009, 106, 16321-16326. [CrossRef]

63. Mikulski, P.; Komarynets, O.; Fachinelli, F.; Weber, A.P.M.; Schubert, D. Characterization of the Polycomb-Group Mark H3K27me3 in Unicellular Algae. Front. Plant Sci. 2017, 8, 607. [CrossRef] [PubMed]

64. Dumesic, P.A.; Homer, C.M.; Moresco, J.J.; Pack, L.R.; Shanle, E.K.; Coyle, S.M.; Strahl, B.D.; Fujimori, D.G.; Yates, J.R.; Madhani, H.D. Product Binding Enforces the Genomic Specificity of a Yeast Polycomb Repressive Complex. Cell 2015, 160, 204-218. [CrossRef]

65. Zhao, X.; Rastogi, A.; Deton Cabanillas, A.F.; Ait Mohamed, O.; Cantrel, C.; Lombard, B.; Murik, O.; Genovesio, A.; Bowler, C.; Bouyer, D.; et al. Genome Wide Natural Variation of H3K27me3 Selectively Marks Genes Predicted to Be Important for Cell Differentiation in Phaeodactylum Tricornutum. New Phytol. 2021, 229, 3208-3220. [CrossRef] [PubMed]

66. Gall Trošelj, K.; Novak Kujundzic, R.; Ugarkovic, D. Polycomb Repressive Complex's Evolutionary Conserved Function: The Role of EZH2 Status and Cellular Background. Clin. Epigenet. 2016, 8, 55. [CrossRef]

67. Deevy, O.; Bracken, A.P. PRC2 Functions in Development and Congenital Disorders. Development 2019, 146, dev181354. [CrossRef]

68. Lewis, Z.A. Polycomb Group Systems in Fungi: New Models for Understanding Polycomb Repressive Complex 2. Trends Genet. 2017, 33, 220-231. [CrossRef] [PubMed]

69. Derkacheva, M.; Hennig, L. Variations on a Theme: Polycomb Group Proteins in Plants. J. Exp. Bot. 2014, 65, 2769-2784. [CrossRef] [PubMed]

70. Smits, A.H.; Jansen, P.W.T.C.; Poser, I.; Hyman, A.A.; Vermeulen, M. Stoichiometry of Chromatin-Associated Protein Complexes Revealed by Label-Free Quantitative Mass Spectrometry-Based Proteomics. Nucleic Acids Res. 2013, 41, e28. [CrossRef]

71. Laugesen, A.; Højfeldt, J.W.; Helin, K. Molecular Mechanisms Directing PRC2 Recruitment and H3K27 Methylation. Mol. Cell 2019, 74, 8-18. [CrossRef] [PubMed]

72. Huang, Y.; Su, T.; Wang, C.; Dong, L.; Liu, S.; Zhu, Y.; Hao, K.; Xia, Y.; Jiang, Q.; Qin, J. Rbbp4 Suppresses Premature Differentiation of Embryonic Stem Cells. Stem Cell Rep. 2021, 16, 566-581. [CrossRef] [PubMed]

73. Xu, C.; Min, J. Structure and Function of WD40 Domain Proteins. Protein Cell 2011, 2, 202-214. [CrossRef] [PubMed]

74. Hauri, S.; Comoglio, F.; Seimiya, M.; Gerstung, M.; Glatter, T.; Hansen, K.; Aebersold, R.; Paro, R.; Gstaiger, M.; Beisel, C. A High-Density Map for Navigating the Human Polycomb Complexome. Cell Rep. 2016, 17, 583-595. [CrossRef] [PubMed]

75. Margueron, R.; Reinberg, D. The Polycomb Complex PRC2 and Its Mark in Life. Nature 2011, 469, 343-349. [CrossRef]

76. Giner-Laguarda, N.; Vidal, M. Functions of Polycomb Proteins on Active Targets. Epigenomes 2020, 4, 17. [CrossRef]

77. Kasinath, V.; Beck, C.; Sauer, P.; Poepsel, S.; Kosmatka, J.; Faini, M.; Toso, D.; Aebersold, R.; Nogales, E. JARID2 and AEBP2 Regulate PRC2 in the Presence of H2AK119ub1 and Other Histone Modifications. Science 2021, 371, eabc3393. [CrossRef]

78. Han, Z.; Xing, X.; Hu, M.; Zhang, Y.; Liu, P.; Chai, J. Structural Basis of EZH2 Recognition by EED. Structure 2007, 15, 1306-1315. [CrossRef]

79. Jiao, L.; Liu, X. Structural Basis of Histone H3K27 Trimethylation by an Active Polycomb Repressive Complex 2. Science 2015, 350, aac4383. [CrossRef]

80. Bratkowski, M.; Yang, X.; Liu, X. Polycomb Repressive Complex 2 in an Autoinhibited State. J. Biol. Chem. 2017, 292, 13323-13332. [CrossRef] [PubMed]

81. Uckelmann, M.; Davidovich, C. Not Just a Writer: PRC2 as a Chromatin Reader. Biochem. Soc. Trans. 2021, 49, 1159-1170. [CrossRef]

82. Shi, Y.; Wang, X.X.; Zhuang, Y.W.; Jiang, Y.; Melcher, K.; Xu, H.E. Structure of the PRC2 Complex and Application to Drug Discovery. Acta Pharmacol. Sin. 2017, 38, 963-976. [CrossRef]

83. Moritz, L.E.; Trievel, R.C. Structure, Mechanism, and Regulation of Polycomb-Repressive Complex 2. J. Biol. Chem. 2018, 293, 13805-13814. [CrossRef]

84. Chammas, P.; Mocavini, I.; Di Croce, L. Engaging Chromatin: PRC2 Structure Meets Function. Br. J. Cancer 2020, 122, 315-328. [CrossRef] [PubMed]

85. The PyMOL Molecular Graphics System; Version 2.4.1; Schrödinger, LLC.: New York, NY, USA, 2020.

86. Kasinath, V.; Nogales, E.; Beck, C.; Sauer, P.; Poepsel, S.; Kosmatka, J.; Faini, M.; Toso, D.; Aebersold, R. PRC2-AEBP2JARID2 Bound to H2AK119ub1 Nucleosome. Available online: https:/ / www.wwpdb.org/pdb?id=pdb_00006wkr (accessed on 20 November 2021). [CrossRef] 
87. Li, L.; Zhang, H.; Zhang, M.; Zhao, M.; Feng, L.; Luo, X.; Gao, Z.; Huang, Y.; Ardayfio, O.; Zhang, J.H.; et al. Discovery and Molecular Basis of a Diverse Set of Polycomb Repressive Complex 2 Inhibitors Recognition by EED. PLoS ONE 2017, 12, e0169855. [CrossRef] [PubMed]

88. Blackledge, N.P.; Klose, R.J. The Molecular Principles of Gene Regulation by Polycomb Repressive Complexes. Nat. Rev. Mol. Cell Biol. 2021, 22, 815-833. [CrossRef]

89. Huang, Y.; Chen, D.H.; Liu, B.Y.; Shen, W.H.; Ruan, Y. Conservation and Diversification of Polycomb Repressive Complex 2 (PRC2) Proteins in the Green Lineage. Brief. Funct. Genom. 2017, 16, 106-119. [CrossRef]

90. Chen, L.J.; Diao, Z.Y.; Specht, C.; Sung, Z.R. Molecular Evolution of VEF-Domain-Containing PcG Genes in Plants. Mol. Plant 2009, 2, 738-754. [CrossRef]

91. Luo, M.; Platten, D.; Chaudhury, A.; Peacock, W.J.; Dennis, E.S. Expression, Imprinting, and Evolution of Rice Homologs of the Polycomb Group Genes. Mol. Plant 2009, 2, 711-723. [CrossRef] [PubMed]

92. Nakamura, M.; Batista, R.A.; Köhler, C.; Hennig, L. Polycomb Repressive Complex 2-Mediated Histone Modification H3K27me3 Is Associated with Embryogenic Potential in Norway Spruce. J. Exp. Bot. 2020, 71, 6366-6378. [CrossRef] [PubMed]

93. Liu, X.; Zhou, C.; Zhao, Y.; Zhou, S.; Wang, W.; Zhou, D.X. The Rice Enhancer of Zeste [E(z)] Genes SDG711 and SDG718 Are Respectively Involved in Long Day and Short Day Signaling to Mediate the Accurate Photoperiod Control of Flowering Time. Front. Plant Sci. 2014, 5, 591. [CrossRef] [PubMed]

94. Ni, J.; Ma, X.; Feng, Y.; Tian, Q.; Wang, Y.; Xu, N.; Tang, J.; Wang, G. Updating and Interaction of Polycomb Repressive Complex 2 Components in Maize (Zea Mays). Planta 2019, 250, 573-588. [CrossRef]

95. Cheng, X.; Pan, M.; Zhiguo, E.; Zhou, Y.; Niu, B.; Chen, C. The Maternally Expressed Polycomb Group Gene OsEMF2a Is Essential for Endosperm Cellularization and Imprinting in Rice. Plant Commun. 2020, 2, 100092. [CrossRef] [PubMed]

96. Conrad, L.J.; Khanday, I.; Johnson, C.; Guiderdoni, E.; An, G.; Vijayraghavan, U.; Sundaresan, V. The Polycomb Group Gene EMF2B Is Essential for Maintenance of Floral Meristem Determinacy in Rice. Plant J. 2014, 80, 883-894. [CrossRef] [PubMed]

97. Strejčková, B.; Čegan, R.; Pecinka, A.; Milec, Z.; Šafář, J. Identification of Polycomb Repressive Complex 1 and 2 Core Components in Hexaploid Bread Wheat. BMC Plant Biol. 2020, 20, 175. [CrossRef]

98. Higgins, J.A.; Bailey, P.C.; Laurie, D.A. Comparative Genomics of Flowering Time Pathways Using Brachypodium Distachyon as a Model for the Temperate Grasses. PLoS ONE 2010, 5, e10065. [CrossRef]

99. Lomax, A.; Woods, D.P.; Dong, Y.; Bouché, F.; Rong, Y.; Mayer, K.S.; Zhong, X.; Amasino, R.M. An Ortholog of CURLY LEAF/ENHANCER OF ZESTE like-1 Is Required for Proper Flowering in Brachypodium Distachyon. Plant J. 2018, 93, 871-882. [CrossRef]

100. Kapazoglou, A.; Tondelli, A.; Papaefthimiou, D.; Ampatzidou, H.; Francia, E.; Stanca, M.A.; Bladenopoulos, K.; Tsaftaris, A.S Epigenetic Chromatin Modifiers in Barley: IV. The Study of Barley Polycomb Group (PcG) Genes during Seed Development and in Response to External ABA. BMC Plant Biol. 2010, 10, 73. [CrossRef] [PubMed]

101. Tonosaki, K.; Kinoshita, T. Possible Roles for Polycomb Repressive Complex 2 in Cereal Endosperm. Front. Plant Sci. 2015, 6, 144. [CrossRef]

102. Derkacheva, M.; Steinbach, Y.; Wildhaber, T.; Mozgová, I.; Mahrez, W.; Nanni, P.; Bischof, S.; Gruissem, W.; Hennig, L. Arabidopsis MSI1 Connects LHP1 to PRC2 Complexes. EMBO J. 2013, 32, 2073-2085. [CrossRef]

103. Zhao, X.; Deton Cabanillas, A.F.; Veluchamy, A.; Bowler, C.; Vieira, F.R.J.; Tirichine, L. Probing the Diversity of Polycomb and Trithorax Proteins in Cultured and Environmentally Sampled Microalgae. Front. Mar. Sci. 2020, 7, 189. [CrossRef]

104. Bourdareau, S.; Tirichine, L.; Lombard, B.; Loew, D.; Scornet, D.; Wu, Y.; Coelho, S.M.; Cock, J.M. Histone Modifications during the Life Cycle of the Brown Alga Ectocarpus. Genome Biol. 2021, 22, 12. [CrossRef]

105. Rzeszutek, I.; Maurer-Alcalá, X.X.; Nowacki, M. Programmed Genome Rearrangements in Ciliates. Cell. Mol. Life Sci. 2020, 77, 4615-4629. [CrossRef]

106. Frapporti, A.; Miró Pina, C.; Arnaiz, O.; Holoch, D.; Kawaguchi, T.; Humbert, A.; Eleftheriou, E.; Lombard, B.; Loew, D.; Sperling, L.; et al. The Polycomb Protein Ezl1 Mediates H3K9 and H3K27 Methylation to Repress Transposable Elements in Paramecium. Nat. Commun. 2019, 10, 2710. [CrossRef] [PubMed]

107. Xu, J.; Zhao, X.; Mao, F.; Basrur, V.; Ueberheide, B.; Chait, B.T.; David Allis, C.; Taverna, S.D.; Gao, S.; Wang, W.; et al. A Polycomb Repressive Complex Is Required for RNAi-Mediated Heterochromatin Formation and Dynamic Distribution of Nuclear Bodies. Nucleic Acids Res. 2021, 49, 5407-5425. [CrossRef]

108. Nabeel-Shah, S.; Garg, J.; Saettone, A.; Ashraf, K.; Lee, H.; Wahab, S.; Ahmed, N.; Fine, J.; Derynck, J.; Pu, S.; et al. Functional Characterization of RebL1 Highlights the Evolutionary Conservation of Oncogenic Activities of the RBBP4/7 Orthologue in Tetrahymena Thermophila. Nucleic Acids Res. 2021, 49, 6196-6212. [CrossRef]

109. Ridenour, J.B.; Möller, M.; Freitag, M. Polycomb Repression without Bristles: Facultative Heterochromatin and Genome Stability in Fungi. Genes 2020, 11, 638. [CrossRef]

110. Connolly, L.R.; Smith, K.M.; Freitag, M. The Fusarium Graminearum Histone H3 K27 Methyltransferase KMT6 Regulates Development and Expression of Secondary Metabolite Gene Clusters. PLoS Genet. 2013, 9, e1003916. [CrossRef]

111. Jamieson, K.; Rountree, M.R.; Lewis, Z.A.; Stajich, J.E.; Selker, E.U. Regional Control of Histone H3 Lysine 27 Methylation in Neurospora. Proc. Natl. Acad. Sci. USA 2013, 110, 6027-6032. [CrossRef]

112. McNaught, K.J.; Wiles, E.T.; Selker, E.U. Identification of a PRC2 Accessory Subunit Required for Subtelomeric H3K27 Methylation in Neurospora Crassa. Mol. Cell. Biol. 2020, 40, e00003-20. [CrossRef] 
113. Sebé-Pedrós, A.; Ballaré, C.; Parra-Acero, H.; Chiva, C.; Tena, J.J.; Sabidó, E.; Gómez-Skarmeta, J.L.; Di Croce, L.; Ruiz-Trillo, I. The Dynamic Regulatory Genome of Capsaspora and the Origin of Animal Multicellularity. Cell 2016, 165, 1224-1237. [CrossRef]

114. Gaiti, F.; Jindrich, K.; Fernandez-Valverde, S.L.; Roper, K.E.; Degnan, B.M.; Tanurdžić, M. Landscape of Histone Modifications in a Sponge Reveals the Origin of Animal Cis-Regulatory Complexity. eLife 2017, 6, e22194. [CrossRef] [PubMed]

115. Genikhovich, G.; Kürn, U.; Hemmrich, G.; Bosch, T.C.G. Discovery of Genes Expressed in Hydra Embryogenesis. Dev. Biol. 2006, 289, 466-481. [CrossRef] [PubMed]

116. Pillai, A.; Gungi, A.; Reddy, P.C.; Galande, S. Epigenetic Regulation in Hydra: Conserved and Divergent Roles. Front. Cell Dev. Biol. 2021, 9, 663208. [CrossRef] [PubMed]

117. PREDICTED: Polycomb Protein Suz12-like [Hydra Vulgaris]. Available online: Https:/ Www.Ncbi.Nlm.Nih.Gov/Protein/XP_ 012556196.1? Report=genbank\&log $\$=$ prottop\&blast_rank=1\&RID=R2KAB9PA013 (accessed on 21 October 2021).

118. PREDICTED: Histone-Binding Protein RBBP7 [Hydra Vulgaris]. Available online: Https:/ /Www.Ncbi.Nlm.Nih.Gov /Protein/ XP_012554465.1?Report=genbank\&log $\$=$ prottop\&blast_rank=1\&RID=R2KUGECN013 (accessed on 21 October 2021).

119. Herz, H.-M.; Mohan, M.; Garrett, A.S.; Miller, C.; Casto, D.; Zhang, Y.; Seidel, C.; Haug, J.S.; Florens, L.; Washburn, M.P.; et al. Polycomb Repressive Complex 2-Dependent and -Independent Functions of Jarid2 in Transcriptional Regulation in Drosophila. Mol. Cell. Biol. 2012, 32, 1683-1693. [CrossRef] [PubMed]

120. Tolhuis, B.; Muijrers, I.; de Wit, E.; Teunissen, H.; Talhout, W.; van Steensel, B.; van Lohuizen, M. Genome-Wide Profiling of PRC1 and PRC2 Polycomb Chromatin Binding in Drosophila Melanogaster. Nat. Genet. 2006, 38, 694-699. [CrossRef] [PubMed]

121. Siebold, A.P.; Banerjee, R.; Tie, F.; Kiss, D.L.; Moskowitz, J.; Harte, P.J. Polycomb Repressive Complex 2 and Trithorax Modulate Drosophila Longevity and Stress Resistance. Proc. Natl. Acad. Sci. USA 2010, 107, 169. [CrossRef] [PubMed]

122. Bender, L.B.; Cao, R.; Zhang, Y.; Strome, S. The MES-2/MES-3/MES-6 Complex and Regulation of Histone H3 Methylation in C. Elegans. Curr. Biol. 2004, 14, 1639-1643. [CrossRef]

123. Gaydos, L.J.; Wang, W.; Strome, S. H3K27me and PRC2 Transmit a Memory of Repression across Generations and during Development. Science 2014, 345, 1515-1518. [CrossRef] [PubMed]

124. Brooun, A.; Gajiwala, K.S.; Deng, Y.L.; Liu, W.; Bolaños, B.; Bingham, P.; He, Y.A.; Diehl, W.; Grable, N.; Kung, P.P.; et al. Polycomb Repressive Complex 2 Structure with Inhibitor Reveals a Mechanism of Activation and Drug Resistance. Nat. Commun. 2016, 7, 11384. [CrossRef]

125. PREDICTED: LOW QUALITY PROTEIN: Polycomb Protein SUZ12 [Anolis Carolinensis]. Available online: Https://Www Ncbi.Nlm.Nih.Gov /Protein/XP_008112590.1?Report=genbank\&log\$=prottop\&blast_rank=1\&RID=R2PMHJ83016 (accessed on 21 October 2021).

126. PREDICTED: Polycomb Protein EED [Anolis Carolinensis]. Available online: Https://Www.Ncbi.Nlm.Nih.Gov/Protein/XP_00 3219406.1?Report=genbank\&log $\$=$ prottop\&blast_rank=1\&RID=R2PDKH5B013 (accessed on 21 October 2021).

127. PREDICTED: Histone-Binding Protein RBBP4 Isoform X2 [Anolis Carolinensis]. Available online: Https://Www.Ncbi. Nlm.Nih.Gov /Protein/XP_003230003.3?Report=genbank\&log $\$=$ prottop\&blast_rank=1\&RID=R2P2UE3N013 (accessed on 21 October 2021).

128. Grossniklaus, U.; Paro, R. Transcriptional Silencing by Polycomb Group Proteins Cellular Memory. Cold Spring Harb. Perspect. Biol. 2014, 6, a019331. [CrossRef]

129. He, A.; Ma, Q.; Cao, J.; von Gise, A.; Zhou, P.; Xie, H.; Zhang, B.; Hsing, M.; Christodoulou, D.C.; Cahan, P.; et al. Polycomb Repressive Complex 2 Regulates Normal Development of the Mouse Heart. Circ. Res. 2012, 110, 406-415. [CrossRef] [PubMed]

130. Hennig, L.; Taranto, P.; Walser, M.; Schönrock, N.; Gruissem, W. Arabidopsis MSI1 Is Required for Epigenetic Maintenance of Reproductive Development. Development 2003, 130, 2555-2565. [CrossRef]

131. Köhler, C.; Hennig, L.; Bouveret, R.; Gheyselinck, J.; Grossniklaus, U.; Gruissem, W. Arabidopsis MSI1 Is a Component of the MEA/FIE Polycomb Group Complex and Required for Seed Development. EMBO J. 2003, 22, 4804-4814. [CrossRef] [PubMed]

132. Hennig, L.; Bouveret, R.; Gruissem, W. MSI1-like Proteins: An Escort Service for Chromatin Assembly and Remodeling Complexes. Trends Cell Biol. 2005, 15, 295-302. [CrossRef]

133. Doyle, M.R.; Amasino, R.M. A Single Amino Acid Change in the Enhancer of Zeste Ortholog CURLY LEAF Results in Vernalization-Independent, Rapid Flowering in Arabidopsis. Plant Physiol. 2009, 151, 1688-1697. [CrossRef]

134. Xu, M.; Hu, T.; Smith, M.R.; Poethig, R.S. Epigenetic Regulation of Vegetative Phase Change in Arabidopsis. Plant Cell 2016, 28, 28-41. [CrossRef] [PubMed]

135. Schubert, D.; Primavesi, L.; Bishopp, A.; Roberts, G.; Doonan, J.; Jenuwein, T.; Goodrich, J. Silencing by Plant Polycomb-Group Genes Requires Dispersed Trimethylation of Histone H3 at Lysine 27. EMBO J. 2006, 25, 4638-4649. [CrossRef] [PubMed]

136. Chanvivattana, Y.; Bishopp, A.; Schubert, D.; Stock, C.; Moon, Y.H.; Sung, Z.R.; Goodrich, J. Interaction of Polycomb-Group Proteins Controlling Flowering in Arabidopsis. Development 2004, 131, 5263-5276. [CrossRef]

137. Aichinger, E.; Villar, C.B.R.; Farrona, S.; Reyes, J.C.; Hennig, L.; Köhler, C. CHD3 Proteins and Polycomb Group Proteins Antagonistically Determine Cell Identity in Arabidopsis. PLoS Genet. 2009, 5, e1000605. [CrossRef] [PubMed]

138. Aichinger, E.; Villar, C.B.R.; Di Mambro, R.; Sabatini, S.; Köhler, C. The CHD3 Chromatin Remodeler PICKLE and Polycomb Group Proteins Antagonistically Regulate Meristem Activity in the Arabidopsis Root. Plant Cell 2011, 23, 1047-1060. [CrossRef]

139. Simonini, S.; Bemer, M.; Bencivenga, S.; Gagliardini, V.; Pires, N.D.; Desvoyes, B.; van der Graaff, E.; Gutierrez, C.; Grossniklaus, U. The Polycomb Group Protein MEDEA Controls Cell Proliferation and Embryonic Patterning in Arabidopsis. Dev. Cell 2021, 56, 1945-1960.e7. [CrossRef] [PubMed] 
140. Moon, Y.H.; Chen, L.; Pan, R.L.; Chang, H.S.; Zhu, T.; Maffeo, D.M.; Sung, Z.R. Erratum: EMF Genes Maintain Vegetative Development by Repressing the Flower Program in Arabidopsis. Plant Cell 2003, 15, 681-693. [CrossRef]

141. De Lucia, F.; Crevillen, P.; Jones, A.M.E.; Greb, T.; Dean, C. A PHD-Polycomb Repressive Complex 2 Triggers the Epigenetic Silencing of FLC during Vernalization. Proc. Natl. Acad. Sci. USA 2008, 105, 16831-16836. [CrossRef] [PubMed]

142. Zhang, S.; Wang, D.; Zhang, H.; Skaggs, M.I.; Lloyd, A.; Ran, D.; An, L.; Schumaker, K.S.; Drews, G.N.; Yadegari, R. FERTILIZATION-INDEPENDENT SEED-Polycomb Repressive Complex 2 Plays a Dual Role in Regulating Type i MADSBox Genes in Early Endosperm Development. Plant Physiol. 2018, 177, 285-299. [CrossRef]

143. Bloomer, R.H.; Hutchison, C.E.; Bäurle, I.; Walker, J.; Fang, X.; Perera, P.; Velanis, C.N.; Gümüs, S.; Spanos, C.; Rappsilber, J.; et al. The Arabidopsis Epigenetic Regulator ICU11 as an Accessory Protein of Polycomb Repressive Complex 2. Proc. Natl. Acad. Sci. USA 2020, 117, 16660. [CrossRef]

144. Zhou, Y.; Wang, Y.; Krause, K.; Yang, T.; Dongus, J.A.; Zhang, Y.; Turck, F. Telobox Motifs Recruit CLF/SWN-PRC2 for H3K27me3 Deposition via TRB Factors in Arabidopsis. Nat. Genet. 2018, 50, 638-644. [CrossRef]

145. Hohenstatt, M.L.; Mikulski, P.; Komarynets, O.; Klose, C.; Kycia, I.; Jeltsch, A.; Farrona, S.; Schubert, D. PWWP-DOMAIN INTERACTOR OF POLYCOMBS1 Interacts with Polycomb-Group Proteins and Histones and Regulates Arabidopsis Flowering and Development. Plant Cell 2018, 30, 117-133. [CrossRef]

146. Yuan, L.; Song, X.; Zhang, L.; Yu, Y.; Liang, Z.; Lei, Y.; Ruan, J.; Tan, B.; Liu, J.; Li, C. The Transcriptional Repressors VAL1 and VAL2 Recruit PRC2 for Genome-Wide Polycomb Silencing in Arabidopsis. Nucleic Acids Res. 2021, 49, 98-113. [CrossRef]

147. Zhang, P.; Zhu, C.; Geng, Y.; Wang, Y.; Yang, Y.; Liu, Q.; Guo, W.; Chachar, S.; Riaz, A.; Yan, S.; et al. Rice and Arabidopsis Homologs of Yeast CHROMOSOME TRANSMISSION FIDELITY PROTEIN 4 Commonly Interact with Polycomb Complexes but Exert Divergent Regulatory Functions. Plant Cell 2021, 33, 1417-1429. [CrossRef]

148. Velanis, C.N.; Perera, P.; Thomson, B.; de Leau, E.; Liang, S.C.; Hartwig, B.; Förderer, A.; Thornton, H.; Arede, P.; Chen, J.; et al. The Domesticated Transposase ALP2 Mediates Formation of a Novel Polycomb Protein Complex by Direct Interaction with MSI1, a Core Subunit of Polycomb Repressive Complex 2 (PRC2). PLoS Genet. 2020, 16, e1008681. [CrossRef]

149. Zhou, Y.; Tergemina, E.; Cui, H.; Förderer, A.; Hartwig, B.; Velikkakam James, G.; Schneeberger, K.; Turck, F. Ctf4-Related Protein Recruits LHP1-PRC2 to Maintain H3K27me3 Levels in Dividing Cells in Arabidopsis thaliana. Proc. Natl. Acad. Sci. USA 2017, 114, 4833. [CrossRef] [PubMed]

150. Jacob, Y.; Feng, S.; LeBlanc, C.A.; Bernatavichute, Y.V.; Stroud, H.; Cokus, S.; Johnson, L.M.; Pellegrini, M.; Jacobsen, S.E.; Michaels, S.D. ATXR5 and ATXR6 Are H3K27 Monomethyltransferases Required for Chromatin Structure and Gene Silencing. Nat. Struct. Mol. Biol. 2009, 16, 763-768. [CrossRef]

151. Schwartz, Y.B.; Kahn, T.G.; Nix, D.A.; Li, X.-Y.; Bourgon, R.; Biggin, M.; Pirrotta, V. Genome-Wide Analysis of Polycomb Targets in Drosophila Melanogaster. Nat. Genet. 2006, 38, 700-705. [CrossRef]

152. Crispatzu, G.; Rehimi, R.; Pachano, T.; Bleckwehl, T.; Cruz-Molina, S.; Xiao, C.; Mahabir, E.; Bazzi, H.; Rada-Iglesias, A. The Chromatin, Topological and Regulatory Properties of Pluripotency-Associated Poised Enhancers Are Conserved in Vivo. Nat. Commun. 2021, 12, 4344. [CrossRef] [PubMed]

153. Chan, H.L.; Beckedorff, F.; Zhang, Y.; Garcia-Huidobro, J.; Jiang, H.; Colaprico, A.; Bilbao, D.; Figueroa, M.E.; LaCava, J.; Shiekhattar, R.; et al. Polycomb Complexes Associate with Enhancers and Promote Oncogenic Transcriptional Programs in Cancer through Multiple Mechanisms. Nat. Commun. 2018, 9, 3377. [CrossRef]

154. Roudier, F.; Ahmed, I.; Bérard, C.; Sarazin, A.; Mary-Huard, T.; Cortijo, S.; Bouyer, D.; Caillieux, E.; Duvernois-Berthet, E.; Al-Shikhley, L.; et al. Integrative Epigenomic Mapping Defines Four Main Chromatin States in Arabidopsis. EMBO J. 2011, 30, 1928-1938. [CrossRef]

155. Sequeira-Mendes, J.; Aragüez, I.; Peiró, R.; Mendez-Giraldez, R.; Zhang, X.; Jacobsen, S.E.; Bastolla, U.; Gutierrez, C. The Functional Topography of the Arabidopsis Genome Is Organized in a Reduced Number of Linear Motifs of Chromatin States. Plant Cell 2014, 26, 2351-2366. [CrossRef]

156. Yu, N.; Nützmann, H.W.; Macdonald, J.T.; Moore, B.; Field, B.; Berriri, S.; Trick, M.; Rosser, S.J.; Kumar, S.V.; Freemont, P.S.; et al. Delineation of Metabolic Gene Clusters in Plant Genomes by Chromatin Signatures. Nucleic Acids Res. 2016, 44, $2255-2265$. [CrossRef] [PubMed]

157. Lafos, M.; Kroll, P.; Hohenstatt, M.L.; Thorpe, F.L.; Clarenz, O.; Schubert, D. Dynamic Regulation of H3K27 Trimethylation during Arabidopsis Differentiation. PLoS Genet. 2011, 7, e1002040. [CrossRef] [PubMed]

158. Bellegarde, F.; Herbert, L.; Séré, D.; Caillieux, E.; Boucherez, J.; Fizames, C.; Roudier, F.; Gojon, A.; Martin, A. Polycomb Repressive Complex 2 Attenuates the Very High Expression of the Arabidopsis Gene NRT2.1. Sci. Rep. 2018, 8, 7905. [CrossRef]

159. Park, E.Y.; Tsuyuki, K.M.; Hu, F.; Lee, J.; Jeong, J. PRC2-Mediated H3K27me3 Contributes to Transcriptional Regulation of FIT-Dependent Iron Deficiency Response. Front. Plant Sci. 2019, 10, 627. [CrossRef]

160. Sani, E.; Herzyk, P.; Perrella, G.; Colot, V.; Amtmann, A. Hyperosmotic Priming of Arabidopsis Seedlings Establishes a Long-Term Somatic Memory Accompanied by Specific Changes of the Epigenome. Genome Biol. 2013, 14, R59. [CrossRef]

161. Chica, C.; Louis, A.; Roest Crollius, H.; Colot, V.; Roudier, F. Comparative Epigenomics in the Brassicaceae Reveals Two Evolutionarily Conserved Modes of PRC2-Mediated Gene Regulation. Genome Biol. 2017, 18, 207. [CrossRef]

162. Lämke, J.; Bäurle, I. Epigenetic and Chromatin-Based Mechanisms in Environmental Stress Adaptation and Stress Memory in Plants. Genome Biol. 2017, 18, 124. [CrossRef] [PubMed] 
163. Kim, J.-M.; Sasaki, T.; Ueda, M.; Sako, K.; Seki, M. Chromatin Changes in Response to Drought, Salinity, Heat, and Cold Stresses in Plants. Front. Plant Sci. 2015, 6, 114. [CrossRef] [PubMed]

164. You, Y.; Sawikowska, A.; Neumann, M.; Posé, D.; Capovilla, G.; Langenecker, T.; Neher, R.A.; Krajewski, P.; Schmid, M. Temporal Dynamics of Gene Expression and Histone Marks at the Arabidopsis Shoot Meristem during Flowering. Nat. Commun. 2017, 8, 207. [CrossRef]

165. Veluchamy, A.; Rastogi, A.; Lin, X.; Lombard, B.; Murik, O.; Thomas, Y.; Dingli, F.; Rivarola, M.; Ott, S.; Liu, X.; et al. An Integrative Analysis of Post-Translational Histone Modifications in the Marine Diatom Phaeodactylum Tricornutum. Genome Biol. 2015, 16, 102. [CrossRef] [PubMed]

166. Montgomery, S.A.; Tanizawa, Y.; Galik, B.; Wang, N.; Ito, T.; Mochizuki, T.; Akimcheva, S.; Bowman, J.L.; Cognat, V.; MaréchalDrouard, L.; et al. Chromatin Organization in Early Land Plants Reveals an Ancestral Association between H3K27me3, Transposons, and Constitutive Heterochromatin. Curr. Biol. 2020, 30, 573-588.e7. [CrossRef]

167. Moreno-Romero, J.; Jiang, H.; Santos-González, J.; Köhler, C. Parental Epigenetic Asymmetry of PRC2-Mediated Histone Modifications in the Arabidopsis Endosperm. EMBO J. 2016, 35, 1298-1311. [CrossRef]

168. Ma, Z.; Wang, H.; Cai, Y.; Wang, H.; Niu, K.; Wu, X.; Ma, H.; Yang, Y.; Tong, W.; Liu, F.; et al. Epigenetic Drift of H3K27me3 in Aging Links Glycolysis to Healthy Longevity in Drosophila. Elife 2018, 7, e35368. [CrossRef]

169. Trim Galore. Available online: http:/ / www.Bioinformatics.Babraham.Ac.Uk/Projects/Trim_galore/ (accessed on 7 January 2022).

170. Langmead, B.; Salzberg, S.L. Fast Gapped-Read Alignment with Bowtie 2. Nat. Methods 2012, 9, 357-359. [CrossRef] [PubMed]

171. Li, H.; Handsaker, B.; Wysoker, A.; Fennell, T.; Ruan, J.; Homer, N.; Marth, G.; Abecasis, G.; Durbin, R. 1000 Genome Project Data Processing Subgroup the Sequence Alignment/Map Format and SAMtools. Bioinformatics 2009, 25, 2078-2079. [CrossRef] [PubMed]

172. Robinson, J.T.; Thorvaldsdóttir, H.; Wenger, A.M.; Zehir, A.; Mesirov, J.P. Variant Review with the Integrative Genomics Viewer Cancer Res. 2017, 77, e31-e34. [CrossRef]

173. Ramírez, F.; Ryan, D.P.; Grüning, B.; Bhardwaj, V.; Kilpert, F.; Richter, A.S.; Heyne, S.; Dündar, F.; Manke, T. DeepTools2: A next Generation Web Server for Deep-Sequencing Data Analysis. Nucleic Acids Res. 2016, 44, W160-W165. [CrossRef]

174. Bredesen, B.A.; Rehmsmeier, M. DNA Sequence Models of Genome-Wide Drosophila Melanogaster Polycomb Binding Sites Improve Generalization to Independent Polycomb Response Elements. Nucleic Acids Res. 2019, 47, 7781-7797. [CrossRef] [PubMed]

175. Erokhin, M.; Gorbenko, F.; Lomaev, D.; Mazina, M.Y.; Mikhailova, A.; Garaev, A.K.; Parshikov, A.; Vorobyeva, N.E.; Georgiev, P.; Schedl, P.; et al. Boundaries Potentiate Polycomb Response Element-Mediated Silencing. BMC Biol. 2021, 19, 113. [CrossRef] [PubMed]

176. Kassis, J.A.; Brown, J.L. Polycomb Group Response Elements in Drosophila and Vertebrates. Adv. Genet. 2013, 81, 83-118. [CrossRef]

177. Schorderet, P.; Lonfat, N.; Darbellay, F.; Tschopp, P.; Gitto, S.; Soshnikova, N.; Duboule, D. A Genetic Approach to the Recruitment of PRC2 at the HoxD Locus. PLoS Genet. 2013, 9, e1003951. [CrossRef]

178. Ray, P.; De, S.; Mitra, A.; Bezstarosti, K.; Demmers, J.A.A.; Pfeifer, K.; Kassis, J.A. Combgap Contributes to Recruitment of Polycomb Group Proteins in Drosophila. Proc. Natl. Acad. Sci. USA 2016, 113, 3826-3831. [CrossRef]

179. Du, J.; Kirk, B.; Zeng, J.; Ma, J.; Wang, Q. Three Classes of Response Elements for Human PRC2 and MLL1/2-Trithorax Complexes. Nucleic Acids Res. 2018, 46, 8848-8864. [CrossRef]

180. Lynch, M.D.; Smith, A.J.H.; De Gobbi, M.; Flenley, M.; Hughes, J.R.; Vernimmen, D.; Ayyub, H.; Sharpe, J.A.; Sloane-Stanley, J.A.; Sutherland, L.; et al. An Interspecies Analysis Reveals a Key Role for Unmethylated CpG Dinucleotides in Vertebrate Polycomb Complex Recruitment. EMBO J. 2012, 31, 317-329. [CrossRef] [PubMed]

181. Chen, S.; Jiao, L.; Liu, X.; Yang, X.; Liu, X. A Dimeric Structural Scaffold for PRC2-PCL Targeting to CpG Island Chromatin. Mol. Cell 2020, 77, 1265-1278. [CrossRef] [PubMed]

182. Mendenhall, E.M.; Koche, R.P.; Truong, T.; Zhou, V.W.; Issac, B.; Chi, A.S.; Ku, M.; Bernstein, B.E. GC-Rich Sequence Elements Recruit PRC2 in Mammalian ES Cells. PLoS Genet. 2010, 6, e1001244. [CrossRef] [PubMed]

183. Lodha, M.; Marco, C.F.; Timmermans, M.C.P. The ASYMMETRIC LEAVES Complex Maintains Repression of KNOX Homeobox Genes via Direct Recruitment of Polycomb-Repressive Complex2. Genes Dev. 2013, 27, 596-601. [CrossRef] [PubMed]

184. Berger, N.; Dubreucq, B.; Roudier, F.; Dubos, C.; Lepiniec, L. Transcriptional Regulation of Arabidopsis LEAFY COTYLEDON2 Involves RLE, a Cis-Element That Regulates Trimethylation of Histone H3 at Lysine-27. Plant Cell 2011, 23, 4065-4078. [CrossRef]

185. Xiao, J.; Jin, R.; Yu, X.; Shen, M.; Wagner, J.D.; Pai, A.; Song, C.; Zhuang, M.; Klasfeld, S.; He, C.; et al. Cis and Trans Determinants of Epigenetic Silencing by Polycomb Repressive Complex 2 in Arabidopsis. Nat. Genet. 2017, 49, 1546-1552. [CrossRef] [PubMed]

186. Mu, Y.; Zou, M.; Sun, X.; He, B.; Xu, X.; Liu, Y.; Zhang, L.; Chi, W. BASIC PENTACYSTEINE Proteins Repress Abscisic Acid INSENSITIVE 4 Expression via Direct Recruitment of the Polycomb-Repressive Complex 2 in Arabidopsis Root Development. Plant Cell Physiol. 2017, 58, 607-621. [CrossRef]

187. Fouracre, J.P.; He, J.; Chen, V.J.; Sidoli, S.; Scott Poethig, R. VAL Genes Regulate Vegetative Phase Change via MiR156-Dependent and Independent Mechanisms. PLoS Genet. 2021, 17, e1009626. [CrossRef]

188. Brockdorff, N. Noncoding RNA and Polycomb Recruitment. RNA 2013, 19, 429-442. [CrossRef] [PubMed]

189. Davidovich, C.; Cech, T.R. The Recruitment of Chromatin Modifiers by Long Noncoding RNAs: Lessons from PRC2. Rna 2015, 21, 2007-2022. [CrossRef] 
190. Skourti-Stathaki, K.; Torlai Triglia, E.; Warburton, M.; Voigt, P.; Bird, A.; Pombo, A. R-Loops Enhance Polycomb Repression at a Subset of Developmental Regulator Genes. Mol. Cell 2019, 73, 930-945. [CrossRef] [PubMed]

191. Allison, D.F.; Wang, G.G. R-Loops: Formation, Function, and Relevance to Cell Stress. Cell Stress 2019, 3, 38-46. [CrossRef] [PubMed]

192. Alecki, C.; Chiwara, V.; Sanz, L.A.; Grau, D.; Arias Pérez, O.; Boulier, E.L.; Armache, K.J.; Chédin, F.; Francis, N.J. RNA-DNA Strand Exchange by the Drosophila Polycomb Complex PRC2. Nat. Commun. 2020, 11, 1781. [CrossRef] [PubMed]

193. Chen, P.B.; Chen, H.V.; Acharya, D.; Rando, O.J.; Fazzio, T.G. R Loops Regulate Promoter-Proximal Chromatin Architecture and Cellular Differentiation. Nat. Struct. Mol. Biol. 2015, 22, 999-1007. [CrossRef]

194. Tian, Y.; Zheng, H.; Zhang, F.; Wang, S.; Ji, X.; Xu, C.; He, Y.; Ding, Y. PRC2 Recruitment and H3K27me3 Deposition at FLC Require FCA Binding of COOLAIR. Sci. Adv. 2019, 5, eaau7246. [CrossRef]

195. Csorba, T.; Questa, J.I.; Sun, Q.; Dean, C. Antisense COOLAIR Mediates the Coordinated Switching of Chromatin States at FLC during Vernalization. Proc. Natl. Acad. Sci. USA 2014, 111, 16160-16165. [CrossRef]

196. Ariel, F.; Jegu, T.; Latrasse, D.; Romero-Barrios, N.; Christ, A.; Benhamed, M.; Crespi, M. Noncoding Transcription by Alternative RNA Polymerases Dynamically Regulates an Auxin-Driven Chromatin Loop. Mol. Cell 2014, 55, 383-396. [CrossRef] [PubMed]

197. Cai, L.; Rothbart, S.B.; Lu, R.; Xu, B.; Chen, W.-Y.; Tripathy, A.; Rockowitz, S.; Zheng, D.; Patel, D.J.; Allis, C.D.; et al. An H3K36 Methylation-Engaging Tudor Motif of Polycomb-like Proteins Mediates PRC2 Complex Targeting. Mol. Cell 2013, 49, 571-582. [CrossRef]

198. Schmitges, F.W.; Prusty, A.B.; Faty, M.; Stützer, A.; Lingaraju, G.M.; Aiwazian, J.; Sack, R.; Hess, D.; Li, L.; Zhou, S.; et al. Histone Methylation by PRC2 Is Inhibited by Active Chromatin Marks. Mol. Cell 2011, 42, 330-341. [CrossRef] [PubMed]

199. Yuan, W.; Xu, M.; Huang, C.; Liu, N.; Chen, S.; Zhu, B. H3K36 Methylation Antagonizes PRC2-Mediated H3K27 Methylation. J. Biol. Chem. 2011, 286, 7983-7989. [CrossRef]

200. Finogenova, K.; Bonnet, J.; Poepsel, S.; Schäfer, I.B.; Finkl, K.; Schmid, K.; Litz, C.; Strauss, M.; Benda, C.; Müller, J. Structural Basis for PRC2 Decoding of Active Histone Methylation Marks H3K36me2/3. eLife 2020, 9, e61964. [CrossRef] [PubMed]

201. Van Kruijsbergen, I.; Hontelez, S.; Veenstra, G.J.C. Recruiting Polycomb to Chromatin. Int. J. Biochem. Cell Biol. 2015, 67, 177-187. [CrossRef]

202. Ballaré, C.; Lange, M.; Lapinaite, A.; Martin, G.M.; Morey, L.; Pascual, G.; Liefke, R.; Simon, B.; Shi, Y.; Gozani, O.; et al. Phf19 Links Methylated Lys36 of Histone H3 to Regulation of Polycomb Activity. Nat. Struct. Mol. Biol. 2012, 19, 1257-1265. [CrossRef]

203. Blanco, E.; González-Ramírez, M.; Alcaine-Colet, A.; Aranda, S.; Croce, L.D. The Bivalent Genome: Characterization, Structure, and Regulation. Trends Genet. 2020, 36, 118-131. [CrossRef] [PubMed]

204. Zhang, Q.; Guan, P.; Zhao, L.; Ma, M.; Xie, L.; Li, Y.; Zheng, R.; Ouyang, W.; Wang, S.; Li, H.; et al. Asymmetric Epigenome Maps of Subgenomes Reveal Imbalanced Transcription and Distinct Evolutionary Trends in Brassica Napus. Mol. Plant 2021, 14, 604-619. [CrossRef] [PubMed]

205. Zhao, K.; Kong, D.; Jin, B.; Smolke, C.D.; Rhee, S.Y. A Novel Bivalent Chromatin Associates with Rapid Induction of Camalexin Biosynthesis Genes in Response to a Pathogen Signal in Arabidopsis. elife 2021, 10, e69508. [CrossRef] [PubMed]

206. Hansen, K.H.; Bracken, A.P.; Pasini, D.; Dietrich, N.; Gehani, S.S.; Monrad, A.; Rappsilber, J.; Lerdrup, M.; Helin, K. A Model for Transmission of the H3K27me3 Epigenetic Mark. Nat. Cell Biol. 2008, 10, 1291-1300. [CrossRef] [PubMed]

207. Margueron, R.; Justin, N.; Ohno, K.; Sharpe, M.L.; Son, J.; Iii, W.J.D.; Voigt, P.; Martin, S.; Taylor, W.R.; Marco, V.D.; et al. Role of the Polycomb Protein EED in the Propagation of Repressive Histone Marks. Nature 2009, 461, 762-767. [CrossRef] [PubMed]

208. Exner, V.; Aichinger, E.; Shu, H.; Wildhaber, T.; Alfarano, P.; Caflisch, A.; Gruissem, W.; Köhler, C.; Hennig, L. The Chromodomain of LIKE HETEROCHROMATIN PROTEIN 1 Is Essential for H3K27me3 Binding and Function during Arabidopsis Development. PLoS ONE 2009, 4, e0005335. [CrossRef]

209. Cooper, S.; Dienstbier, M.; Hassan, R.; Schermelleh, L.; Sharif, J.; Blackledge, N.P.; De Marco, V.; Elderkin, S.; Koseki, H.; Klose, R.; et al. Targeting Polycomb to Pericentric Heterochromatin in Embryonic Stem Cells Reveals a Role for H2AK119u1 in PRC2 Recruitment. Cell Rep. 2014, 7, 1456-1470. [CrossRef] [PubMed]

210. Dobrinić, P.; Szczurek, A.T.; Klose, R.J. PRC1 Drives Polycomb-Mediated Gene Repression by Controlling Transcription Initiation and Burst Frequency. Nat. Struct. Mol. Biol. 2021, 28, 811-824. [CrossRef]

211. Blackledge, N.P.; Rose, N.R.; Klose, R.J. Targeting Polycomb Systems to Regulate Gene Expression: Modifications to a Complex Story. Nat. Rev. Mol. Cell Biol. 2015, 16, 643-649. [CrossRef] [PubMed]

212. Barbour, H.; Daou, S.; Hendzel, M.; Affar, E.B. Polycomb Group-Mediated Histone H2A Monoubiquitination in Epigenome Regulation and Nuclear Processes. Nat. Commun. 2020, 11, 5947. [CrossRef]

213. Yin, X.; Romero-Campero, F.J.; de Los Reyes, P.; Yan, P.; Yang, J.; Tian, G.; Yang, X.; Mo, X.; Zhao, S.; Calonje, M.; et al. H2AK121ub in Arabidopsis Associates with a Less Accessible Chromatin State at Transcriptional Regulation Hotspots. Nat. Commun. 2021, 12, 315. [CrossRef] [PubMed]

214. Freitag, M. Histone Methylation by SET Domain Proteins in Fungi. Annu. Rev. Microbiol. 2017, 71, 413-439. [CrossRef]

215. Köhler, C.; Villar, C.B.R. Programming of Gene Expression by Polycomb Group Proteins. Trends Cell Biol. 2008, 18, 236-243. [CrossRef] [PubMed]

216. Trojer, P.; Reinberg, D. Histone Lysine Demethylases and Their Impact on Epigenetics. Cell 2006, 125, 213-217. [CrossRef] [PubMed] 
217. Sharaf, A.; Vijayanathan, M.; Oborník, M.; Mozgová, I. Phylogenetic Profiling Suggests Early Origin of the Core Subunits of Polycomb Repressive Complex 2 (PRC2). 2021. Available online: https://www.biorxiv.org/content/10.1101/2021.07.16.452543v1 .abstract (accessed on 28 December 2021).

218. Margulis, L.; Chapman, M.; Guerrero, R.; Hall, J. The Last Eukaryotic Common Ancestor (LECA): Acquisition of Cytoskeletal Motility from Aerotolerant Spirochetes in the Proterozoic Eon. Proc. Natl. Acad. Sci. USA 2006, 103, 13080. [CrossRef]

219. O'Malley, M.A.; Leger, M.M.; Wideman, J.G.; Ruiz-Trillo, I. Concepts of the Last Eukaryotic Common Ancestor. Nat. Ecol. Evol. 2019, 3, 338-344. [CrossRef] [PubMed]

220. Spillane, C.; Schmid, K.J.; Laoueillé-Duprat, S.; Pien, S.; Escobar-Restrepo, J.M.; Baroux, C.; Gagliardini, V.; Page, D.R.; Wolfe, K.H.; Grossniklaus, U. Positive Darwinian Selection at the Imprinted MEDEA Locus in Plants. Nature 2007, 448, 349-352. [CrossRef] [PubMed]

221. Qiu, Y.; Liu, S.L.; Adams, K.L. Concerted Divergence after Gene Duplication in Polycomb Repressive Complexes. Plant Physiol. 2017, 174, 1192-1204. [CrossRef] [PubMed]

222. Wong, J.T.Y. Architectural Organization of Dinoflagellate Liquid Crystalline Chromosomes. Microorganisms 2019, 7, 27. [CrossRef] [PubMed]

223. Marinov, G.K.; Lynch, M. Diversity and Divergence of Dinoflagellate Histone Proteins. G3: Genes Genomes Genet. 2016, 6, 397-422. [CrossRef] [PubMed]

224. Gornik, S.G.; Ford, K.L.; Mulhern, T.D.; Bacic, A.; McFadden, G.I.; Waller, R.F. Loss of Nucleosomal DNA Condensation Coincides with Appearance of a Novel Nuclear Protein in Dinoflagellates. Curr. Biol. 2012, 22, 2303-2312. [CrossRef]

225. Pan, B.; Chen, X.; Hou, L.; Zhang, Q.; Qu, Z.; Warren, A.; Miao, M. Comparative Genomics Analysis of Ciliates Provides Insights on the Evolutionary History Within "Nassophorea-Synhymenia-Phyllopharyngea" Assemblage. Front. Microbiol. 2019, 10, 2819. [CrossRef]

226. Chalker, D.L.; Meyer, E.; Mochizuki, K. Epigenetics of Ciliates. Cold Spring Harb. Perspect. Biol. 2013, 5, a017764. [CrossRef]

227. Taverna, S.D.; Coyne, R.S.; Allis, C.D. Methylation of Histone H3 at Lysine 9 Targets Programmed DNA Elimination in Tetrahymena. Cell 2002, 110, 701-711. [CrossRef]

228. Liu, Y.; Mochizuki, K.; Gorovsky, M.A. Histone H3 Lysine 9 Methylation Is Required for DNA Elimination in Developing Macronuclei in Tetrahymena. Proc. Natl. Acad. Sci. USA 2004, 101, 1679-1684. [CrossRef] [PubMed]

229. Liu, Y.; Taverna, S.D.; Muratore, T.L.; Shabanowitz, J.; Hunt, D.F.; Allis, C.D. RNAi-Dependent H3K27 Methylation Is Required for Heterochromatin Formation and DNA Elimination in Tetrahymena. Genes Dev. 2007, 21, 1530-1545. [CrossRef]

230. Zhao, X.; Xiong, J.; Mao, F.; Sheng, Y.; Chen, X.; Feng, L.; Dui, W.; Yang, W.; Kapusta, A.; Feschotte, C.; et al. RNAi-Dependent Polycomb Repression Controls Transposable Elements in Tetrahymena. Genes Dev. 2019, 33, 348-364. [CrossRef]

231. Cao, R.; Wang, L.; Wang, H.; Xia, L.; Erdjument-Bromage, H.; Tempst, P.; Jones, R.S.; Zhang, Y. Role of Histone H3 Lysine 27 Methylation in Polycomb-Group Silencing. Science 2002, 298, 1039-1043. [CrossRef] [PubMed]

232. Czermin, B.; Melfi, R.; McCabe, D.; Seitz, V.; Imhof, A.; Pirrotta, V. Drosophila Enhancer of Zeste/ESC Complexes Have a Histone H3 Methyltransferase Activity That Marks Chromosomal Polycomb Sites. Cell 2002, 111, 185-196. [CrossRef]

233. Kuzmichev, A.; Nishioka, K.; Erdjument-Bromage, H.; Tempst, P.; Reinberg, D. Histone Methyltransferase Activity Associated with a Human Multiprotein Complex Containing the Enhancer of Zeste Protein. Genes Dev. 2002, 16, 2893-2905. [CrossRef] [PubMed]

234. Erlendson, A.A.; Friedman, S.; Freitag, M. A Matter of Scale and Dimensions: Chromatin of Chromosome Landmarks in the Fungi. Microbiol. Spectr. 2017, 5. [CrossRef] [PubMed]

235. Smith, K.M.; Kothe, G.O.; Matsen, C.B.; Khlafallah, T.K.; Adhvaryu, K.K.; Hemphill, M.; Freitag, M.; Motamedi, M.R.; Selker, E.U. The Fungus Neurospora Crassa Displays Telomeric Silencing Mediated by Multiple Sirtuins and by Methylation of Histone H3 Lysine 9. Epigenet. Chromatin 2008, 1, 5. [CrossRef] [PubMed]

236. Bratkowski, M.; Yang, X.; Liu, X. An Evolutionarily Conserved Structural Platform for PRC2 Inhibition by a Class of Ezh2 Inhibitors. Sci. Rep. 2018, 8. [CrossRef]

237. Studt, L.; Rösler, S.M.; Burkhardt, I.; Arndt, B.; Freitag, M.; Humpf, H.U.; Dickschat, J.S.; Tudzynski, B. Knock-down of the Methyltransferase Kmt6 Relieves H3K27me3 and Results in Induction of Cryptic and Otherwise Silent Secondary Metabolite Gene Clusters in Fusarium Fujikuroi. Environ. Microbiol. 2016, 18, 4037-4054. [CrossRef]

238. Carlier, F.; Li, M.; Maroc, L.; Debuchy, R.; Souaid, C.; Noordermeer, D.; Grognet, P.; Malagnac, F. Loss of EZH2-like or SU(VAR)39-like Proteins Causes Simultaneous Perturbations in H3K27 and H3K9 Tri-Methylation and Associated Developmental Defects in the Fungus Podospora Anserina. Epigenet. Chromatin 2021, 14, 22. [CrossRef]

239. Ferraro, A.R.; Ameri, A.J.; Lu, Z.; Kamei, M.; Schmitz, R.J.; Lewis, Z.A. Chromatin Accessibility Profiling in Neurospora Crassa Reveals Molecular Features Associated with Accessible and Inaccessible Chromatin. BMC Genom. 2021, 22, 459. [CrossRef]

240. Jiao, L.; Liu, X. Structural Analysis of an Active Fungal PRC2. Nucleus 2016, 7, 284-291. [CrossRef]

241. Srivastava, M.; Simakov, O.; Chapman, J.; Fahey, B.; Gauthier, M.E.A.; Mitros, T.; Richards, G.S.; Conaco, C.; Dacre, M.; Hellsten, U.; et al. The Amphimedon Queenslandica Genome and the Evolution of Animal Complexity. Nature 2010, 466, 720-726. [CrossRef]

242. Müller, W.E.G.; Wiens, M.; Adell, T.; Gamulin, V.; Schröder, H.C.; Müller, I.M. Bauplan of Urmetazoa: Basis for Genetic Complexity of Metazoa. Int. Rev. Cytol. 2004, 235, 53-92. [CrossRef] 
243. Verheul, T.C.J.; van Hijfte, L.; Perenthaler, E.; Barakat, T.S. The Why of YY1: Mechanisms of Transcriptional Regulation by Yin Yang 1. Front. Cell Dev. Biol. 2020, 8, 1034. [CrossRef]

244. Vandamme, J.; Sidoli, S.; Mariani, L.; Friis, C.; Christensen, J.; Helin, K.; Jensen, O.N.; Salcini, A.E. H3K23me2 Is a New Heterochromatic Mark in Caenorhabditis Elegans. Nucleic Acids Res. 2015, 43, 9694-9710. [CrossRef]

245. Ahringer, J.; Gasser, S.M. Repressive Chromatin in Caenorhabditis Elegans: Establishment, Composition, and Function. Genetics 2018, 208, 491-511. [CrossRef]

246. Holdeman, R.; Nehrt, S.; Strome, S. MES-2, a Maternal Protein Essential for Viability of the Germline in Caenorhabditis Elegans, Is Homologous to a Drosophila Polycomb Group Protein. Development 1998, 125, 2457-2467. [CrossRef]

247. Xu, L.; Paulsen, J.; Yoo, Y.; Goodwin, E.B.; Strome, S. Caenorhabditis Elegans MES-3 Is a Target of GLD-1 and Functions Epigenetically in Germline Development. Genetics 2001, 159, 1007-1017. [CrossRef]

248. Guillermo, A.R.R.; Chocian, K.; Gavriilidis, G.; Vandamme, J.; Salcini, A.E.; Mellor, J.; Woollard, A. H3K27 Modifiers Regulate Lifespan in C. Elegans in a Context-Dependent Manner. BMC Biol. 2021, 19, 59. [CrossRef]

249. Matsuzaki, M.; Misumi, O.; Shin-I, T.; Maruyama, S.; Takahara, M.; Miyagishima, S.Y.; Mori, T.; Nishida, K.; Yagisawa, F.; Nishida, K.; et al. Genome Sequence of the Ultrasmall Unicellular Red Alga Cyanidioschyzon Merolae 10D. Nature 2004, 428, 653-657. [CrossRef]

250. Schubert, D. Evolution of Polycomb-Group Function in the Green Lineage. F1000Research 2019, 8, 268. [CrossRef] [PubMed]

251. Xiao, J.; Wagner, D. Polycomb Repression in the Regulation of Growth and Development in Arabidopsis. Curr. Opin. Plant Biol. 2015, 23, 15-24. [CrossRef]

252. Mozgova, I.; Köhler, C.; Hennig, L. Keeping the Gate Closed: Functions of the Polycomb Repressive Complex PRC2 in Development. Plant J. 2015, 83, 121-132. [CrossRef] [PubMed]

253. Yan, B.; Lv, Y.; Zhao, C.; Wang, X. Knowing When to Silence: Roles of Polycomb-Group Proteins in SAM Maintenance, Root Development, and Developmental Phase Transition. Int. J. Mol. Sci. 2020, 21, 5871. [CrossRef]

254. Tonosaki, K.; Ono, A.; Kunisada, M.; Nishino, M.; Nagata, H.; Sakamoto, S.; Kijima, S.T.; Furuumi, H.; Nonomura, K.I.; Sato, Y.; et al. Mutation of the Imprinted Gene OsEMF2a Induces Autonomous Endosperm Development and Delayed Cellularization in Rice. Plant Cell 2021, 33, 85-103. [CrossRef]

255. Springer, N.M.; Danilevskaya, O.N.; Hermon, P.; Helentjaris, T.G.; Phillips, R.L.; Kaeppler, H.F.; Kaeppler, S.M. Sequence Relationships, Conserved Domains, and Expression Patterns for Maize Homologs of the Polycomb Group Genes E(z), Esc, and E(Pc). Plant Physiol. 2002, 128, 1332-1345. [CrossRef]

256. Horst, N.A.; Katz, A.; Pereman, I.; Decker, E.L.; Ohad, N.; Reski, R. A Single Homeobox Gene Triggers Phase Transition, Embryogenesis and Asexual Reproduction. Nat. Plants 2016, 2, 15209. [CrossRef] [PubMed]

257. Widiez, T.; Symeonidi, A.; Luo, C.; Lam, E.; Lawton, M.; Rensing, S.A. The Chromatin Landscape of the Moss Physcomitrella Patens and Its Dynamics during Development and Drought Stress. Plant J. 2014, 79, 67-81. [CrossRef]

258. Goodrich, J.; Puangsomlee, P.; Martin, M.; Long, D.; Meyerowitz, E.M.; Coupland, G. A Polycomb-Group Gene Regulates Homeotic Gene Expression in Arabidopsis. Nature 1997, 386, 44-51. [CrossRef] [PubMed]

259. Grossniklaus, U.; Vielle-Calzada, J.-P.; Hoeppner, M.A.; Gagliano, W.B. Maternal Control of Embryogenesis by MEDEA, a Polycomb Group Gene in Arabidopsis. Science 1998, 280, 446-450. [CrossRef]

260. Danilevskaya, O.N.; Hermon, P.; Hantke, S.; Muszynski, M.G.; Kollipara, K.; Ananiev, E.V. Duplicated Fie Genes in Maize: Expression Pattern and Imprinting Suggest Distinct Functions. Plant Cell 2003, 15, 425-438. [CrossRef]

261. Wang, H.; Liu, C.; Cheng, J.; Liu, J.; Zhang, L.; He, C.; Shen, W.H.; Jin, H.; Xu, L.; Zhang, Y. Arabidopsis Flower and Embryo Developmental Genes Are Repressed in Seedlings by Different Combinations of Polycomb Group Proteins in Association with Distinct Sets of Cis-Regulatory Elements. PLoS Genet. 2016, 12, e1005771. [CrossRef] [PubMed]

262. Pereman, I.; Mosquna, A.; Katz, A.; Wiedemann, G.; Lang, D.; Decker, E.L.; Tamada, Y.; Ishikawa, T.; Nishiyama, T.; Hasebe, M.; et al. The Polycomb Group Protein CLF Emerges as a Specific Tri-Methylase of H3K27 Regulating Gene Expression and Development in Physcomitrella Patens. Biochim. Biophys. Acta (BBA) Gene Regul. Mech. 2016, 1859, 860-870. [CrossRef] [PubMed]

263. Gibbs, D.J.; Tedds, H.M.; Labandera, A.M.; Bailey, M.; White, M.D.; Hartman, S.; Sprigg, C.; Mogg, S.L.; Osborne, R.; Dambire, C.; et al. Oxygen-Dependent Proteolysis Regulates the Stability of Angiosperm Polycomb Repressive Complex 2 Subunit VERNALIZATION 2. Nat. Commun. 2018, 9, 5438. [CrossRef]

264. Katz, A.; Oliva, M.; Mosquna, A.; Hakim, O.; Ohad, N. FIE and CURLY LEAF Polycomb Proteins Interact in the Regulation of Homeobox Gene Expression during Sporophyte Development. Plant J. 2004, 37, 707-719. [CrossRef] [PubMed]

265. He, G.; Zhu, X.; Elling, A.A.; Chen, L.; Wang, X.; Guo, L.; Liang, M.; He, H.; Zhang, H.; Chen, F.; et al. Global Epigenetic and Transcriptional Trends among Two Rice Subspecies and Their Reciprocal Hybrids. Plant Cell 2010, 22, 17-33. [CrossRef] [PubMed]

266. Saripalli, G.; Singh, K.; Gautam, T.; Kumar, S.; Raghuvanshi, S.; Prasad, P.; Jain, N.; Sharma, P.K.; Balyan, H.S.; Gupta, P.K. Genome-Wide Analysis of H3K4me3 and H3K27me3 Modifications Due to Lr28 for Leaf Rust Resistance in Bread Wheat (Triticum Aestivum). Plant Mol. Biol. 2020, 104, 113-136. [CrossRef] [PubMed]

267. Makarevitch, I.; Eichten, S.R.; Briskine, R.; Waters, A.J.; Danilevskaya, O.N.; Meeley, R.B.; Myers, C.L.; Vaughn, M.W.; Springer, N.M. Genomic Distribution of Maize Facultative Heterochromatin Marked by Trimethylation of H3K27. Plant Cell 2013, 25, 780-793. [CrossRef] 
268. Baker, K.; Dhillon, T.; Colas, I.; Cook, N.; Milne, I.; Milne, L.; Bayer, M.; Flavell, A.J. Chromatin State Analysis of the Barley Epigenome Reveals a Higher-Order Structure Defined by H3K27me1 and H3K27me3 Abundance. Plant J. 2015, 84, 111-124. [CrossRef]

269. Payá-Milans, M.; Poza-Viejo, L.; Martín-Uriz, P.S.; Lara-Astiaso, D.; Wilkinson, M.D.; Crevillén, P. Genome-Wide Analysis of the H3K27me3 Epigenome and Transcriptome in Brassica Rapa. GigaScience 2019, 8, giz147. [CrossRef]

270. Huan, Q.; Mao, Z.; Chong, K.; Zhang, J. Global Analysis of H3K4me3/H3K27me3 in Brachypodium Distachyon Reveals VRN3 as Critical Epigenetic Regulation Point in Vernalization and Provides Insights into Epigenetic Memory. New Phytol. 2018, 219, 1373-1387. [CrossRef]

271. Wang, X.; Elling, A.A.; Li, X.; Li, N.; Peng, Z.; He, G.; Sun, H.; Qi, Y.; Liu, X.S.; Deng, X.W. Genome-Wide and Organ-Specific Landscapes of Epigenetic Modifications and Their Relationships to MRNA and Small RNA Transcriptomes in Maize. Plant Cell 2009, 21, 1053-1069. [CrossRef]

272. Fuchs, J.; Jovtchev, G.; Schubert, I. The Chromosomal Distribution of Histone Methylation Marks in Gymnosperms Differs from That of Angiosperms. Chromosome Res. 2008, 16, 891-898. [CrossRef] [PubMed]

273. Liu, S.; Trejo-arellano, M.S.; Qiu, Y.; Eklund, D.M.; Köhler, C.; Hennig, L. H2A Ubiquitination is Essential for Polycomb Repressive Complex 1-Mediated Gene Regulation in Marchantia polymorpha. Genome Biol. 2021, 22, 253. [CrossRef]

274. Lang, D.; Ullrich, K.K.; Murat, F.; Fuchs, J.; Jenkins, J.; Haas, F.B.; Piednoel, M.; Gundlach, H.; Van Bel, M.; Meyberg, R.; et al. The Physcomitrella Patens Chromosome-Scale Assembly Reveals Moss Genome Structure and Evolution. Plant J. 2018, 93, 515-533. [CrossRef] [PubMed]

275. Waterborg, J.H.; Robertson, A.J.; Tatar, D.L.; Borza, C.M.; Davie, J.R. Histones of Chlamydomonas Reinhardtii (Synthesis, Acetylation, and Methylation). Plant Physiol. 1995, 109, 393-407. [CrossRef]

276. Ngan, C.Y.; Wong, C.-H.; Choi, C.; Yoshinaga, Y.; Louie, K.; Jia, J.; Chen, C.; Bowen, B.; Cheng, H.; Leonelli, L.; et al. LineageSpecific Chromatin Signatures Reveal a Regulator of Lipid Metabolism in Microalgae. Nat. Plants 2015, 1, 15107. [CrossRef] [PubMed]

277. Kiyosue, T.; Ohad, N.; Yadegari, R.; Hannon, M.; Dinneny, J.; Wells, D.; Katz, A.; Margossian, L.; Harada, J.J.; Goldberg, R.B.; et al Control of Fertilization-Independent Endosperm Development by the MEDEA Polycomb Gene in Arabidopsis. Proc. Natl. Acad. Sci. USA 1999, 96, 4186. [CrossRef]

278. Ohad, N.; Yadegari, R.; Margossian, L.; Hannon, M.; Michaeli, D.; Harada, J.J.; Goldberg, R.B.; Fischer, R.L. Mutations in FIE, a WD Polycomb Group Gene, Allow Endosperm Development without Fertilization. Plant Cell 1999, 11, 407-415. [CrossRef] [PubMed]

279. Luo, M.; Bilodeau, P.; Koltunow, A.; Dennis, E.S.; Peacock, W.J.; Chaudhury, A.M. Genes Controlling Fertilization-Independent Seed Development in Arabidopsis Thaliana. Proc. Natl. Acad. Sci. USA 1999, 96, 296-301. [CrossRef] [PubMed]

280. Ringrose, L.; Ehret, H.; Paro, R. Distinct Contributions of Histone H3 Lysine 9 and 27 Methylation to Locus-Specific Stability of Polycomb Complexes. Mol. Cell 2004, 16, 641-653. [CrossRef]

281. Kim, J.; Kim, H. Recruitment and Biological Consequences of Histone Modification of H3K27me3 and H3K9me3. ILAR J. 2012, 53, 232-239. [CrossRef] [PubMed]

282. Zervudacki, J.; Yu, A.; Amesefe, D.; Wang, J.; Drouaud, J.; Navarro, L.; Deleris, A. Transcriptional Control and Exploitation of an Immune-Responsive Family of Plant Retrotransposons. EMBO J. 2018, 37, e98482. [CrossRef]

283. Peters, A.H.F.M.; Kubicek, S.; Mechtler, K.; O'Sullivan, R.J.; Derijck, A.A.H.A.; Perez-Burgos, L.; Kohlmaier, A.; Opravil, S.; Tachibana, M.; Shinkai, Y.; et al. Partitioning and Plasticity of Repressive Histone Methylation States in Mammalian Chromatin. Mol. Cell 2003, 12, 1577-1589. [CrossRef]

284. Saksouk, N.; Barth, T.K.; Ziegler-Birling, C.; Olova, N.; Nowak, A.; Rey, E.; Mateos-Langerak, J.; Urbach, S.; Reik, W.; TorresPadilla, M.-E.; et al. Redundant Mechanisms to Form Silent Chromatin at Pericentromeric Regions Rely on BEND3 and DNA Methylation. Mol. Cell 2014, 56, 580-594. [CrossRef]

285. Walter, M.; Teissandier, A.; Pérez-Palacios, R.; Bourc'his, D. An Epigenetic Switch Ensures Transposon Repression upon Dynamic Loss of DNA Methylation in Embryonic Stem Cells. eLife 2016, 5, e11418. [CrossRef]

286. Deleris, A.; Stroud, H.; Bernatavichute, Y.; Johnson, E.; Klein, G.; Schubert, D.; Jacobsen, S.E. Loss of the DNA Methyltransferase MET1 Induces H3K9 Hypermethylation at PcG Target Genes and Redistribution of H3K27 Trimethylation to Transposons in Arabidopsis Thaliana. PLoS Genet. 2012, 8, e1003062. [CrossRef]

287. Mathieu, O.; Probst, A.V.; Paszkowski, J. Distinct Regulation of Histone H3 Methylation at Lysines 27 and 9 by CpG Methylation in Arabidopsis. EMBO J. 2005, 24, 2783-2791. [CrossRef]

288. Weinhofer, I.; Hehenberger, E.; Roszak, P.; Hennig, L.; Köhler, C. H3K27me3 Profiling of the Endosperm Implies Exclusion of Polycomb Group Protein Targeting by DNA Methylation. PLoS Genet. 2010, 6, e1001152. [CrossRef]

289. Moreno-Romero, J.; Del Toro-De León, G.; Yadav, V.K.; Santos-González, J.; Köhler, C. Epigenetic Signatures Associated with Imprinted Paternally Expressed Genes in the Arabidopsis Endosperm. Genome Biol. 2019, 20, 41. [CrossRef]

290. Rougée, M.; Quadrana, L.; Zervudacki, J.; Hure, V.; Colot, V.; Navarro, L.; Deleris, A. Polycomb Mutant Partially Suppresses DNA Hypomethylation-Associated Phenotypes in Arabidopsis. Life Sci. Alliance 2021, 4, e202000848. [CrossRef] [PubMed]

291. Jamieson, K.; Wiles, E.T.; McNaught, K.J.; Sidoli, S.; Leggett, N.; Shao, Y.; Garcia, B.A.; Selker, E.U. Loss of HP1 Causes Depletion of H3K27me3 from Facultative Heterochromatin and Gain of H3K27me2 at Constitutive Heterochromatin. Genome Res. 2016, 26, 97-107. [CrossRef] 
292. Basenko, E.Y.; Sasaki, T.; Ji, L.; Prybol, C.J.; Burckhardt, R.M.; Schmitz, R.J.; Lewis, Z.A. Genome-Wide Redistribution of H3K27me3 Is Linked to Genotoxic Stress and Defective Growth. Proc. Natl. Acad. Sci. USA 2015, 112, E6339-E6348. [CrossRef] [PubMed]

293. Möller, M.; Schotanus, K.; Soyer, J.L.; Haueisen, J.; Happ, K.; Stralucke, M.; Happel, P.; Smith, K.M.; Connolly, L.R.; Freitag, M.; et al. Destabilization of Chromosome Structure by Histone H3 Lysine 27 Methylation. PLoS Genet. 2019, 15, e1008093. [CrossRef]

294. Leeb, M.; Pasini, D.; Novatchkova, M.; Jaritz, M.; Helin, K.; Wutz, A. Polycomb Complexes Act Redundantly to Repress Genomic Repeats and Genes. Genes Dev. 2010, 24, 265-276. [CrossRef]

295. Klocko, A.D.; Ormsby, T.; Galazka, J.M.; Leggett, N.A.; Uesaka, M.; Honda, S.; Freitag, M.; Selker, E.U. Normal Chromosome Conformation Depends on Subtelomeric Facultative Heterochromatin in Neurospora Crassa. Proc. Natl. Acad. Sci. USA 2016, 113, 15048-15053. [CrossRef]

296. Montero, J.J.; López-Silanes, I.; Megías, D.; Fraga, F.M.; Castells-García, Á.; Blasco, M.A. TERRA Recruitment of Polycomb to Telomeres Is Essential for Histone Trymethylation Marks at Telomeric Heterochromatin. Nat. Commun. 2018, 9, 1548. [CrossRef] [PubMed]

297. Majerová, E.; Mandáková, T.; Vu, G.T.H.; Fajkus, J.; Lysak, M.A.; Fojtová, M. Chromatin Features of Plant Telomeric Sequences at Terminal vs. Internal Positions. Front. Plant Sci. 2014, 5, 593. [CrossRef]

298. Adamusová, K.; Khosravi, S.; Fujimoto, S.; Houben, A.; Matsunaga, S.; Fajkus, J.; Fojtová, M. Two Combinatorial Patterns of Telomere Histone Marks in Plants with Canonical and Non-Canonical Telomere Repeats. Plant J. 2020, 102, 678-687. [CrossRef] [PubMed]

299. Bettin, N.; Oss Pegorar, C.; Cusanelli, E. The Emerging Roles of TERRA in Telomere Maintenance and Genome Stability. Cells 2019, 8, 246. [CrossRef]

300. Vrbsky, J.; Akimcheva, S.; Watson, J.M.; Turner, T.L.; Daxinger, L.; Vyskot, B.; Aufsatz, W.; Riha, K. SiRNA-Mediated Methylation of Arabidopsis Telomeres. PLoS Genet. 2010, 6, e1000986. [CrossRef] [PubMed]

301. De Lange, T. Shelterin: The Protein Complex That Shapes and Safeguards Human Telomeres. Genes Dev. 2005, 19, 2100-2110. [CrossRef]

302. Marión, R.M.; Montero, J.J.; de Silanes, I.L.; Graña-Castro, O.; Martínez, P.; Schoeftner, S.; Palacios-Fábrega, J.A.; Blasco, M.A. TERRA Regulate the Transcriptional Landscape of Pluripotent Cells through TRF1-Dependent Recruitment of PRC2. eLife 2019, 8, e44656. [CrossRef] [PubMed]

303. Procházková Schrumpfová, P.; Vychodilová, I.; Dvořáčková, M.; Majerská, J.; Dokládal, L.; Schořová, Š.; Fajkus, J. Telomere Repeat Binding Proteins Are Functional Components of Arabidopsis Telomeres and Interact with Telomerase. Plant J. 2014, 77, 770-781. [CrossRef]

304. Procházková Schrumpfová, P.; Fojtová, M.; Fajkus, J. Telomeres in Plants and Humans: Not So Different, Not So Similar. Cells 2019, 8, 58. [CrossRef] [PubMed]

305. Zhou, Y.; Hartwig, B.; James, G.V.; Schneeberger, K.; Turck, F. Complementary Activities of TELOMERE REPEAT BINDING Proteins and Polycomb Group Complexes in Transcriptional Regulation of Target Genes. Plant Cell 2016, 28, 87-101. [CrossRef]

306. Jamieson, K.; McNaught, K.J.; Ormsby, T.; Leggett, N.A.; Honda, S.; Selker, E.U. Telomere Repeats Induce Domains of H3K27 Methylation in Neurospora. eLife 2018, 7, 87-101. [CrossRef] [PubMed]

307. Teano, G.; Concia, L.; Carron, L.; Wolff, L.; Adamusová, K.; Fojtová, M.; Bourge, M.; Kramdi, A.; Colot, V.; Grossniklaus, U.; et al. Histone H1 Protects Telomeric Repeats from H3K27me3 Invasion in Arabidopsis. bioRxiv 2021. [CrossRef]

308. Marasca, F.; Bodega, B.; Orlando, V. How Polycomb-Mediated Cell Memory Deals With a Changing Environment. BioEssays 2018, 40, 1700137. [CrossRef] 